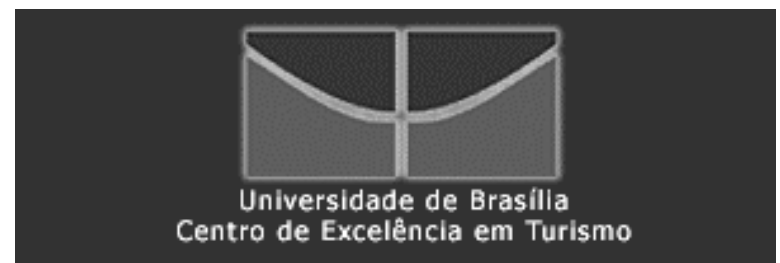

Gestão e Marketing do Turismo V

\title{
O "PONTO DE FÉ" MÍSTICO-RELIGIOSO COMO ATRATIVIDADE TURÍSTICA
}

\author{
Autor: Gleison de Oliveira Carvalho \\ Orientadora: Deis Elucy Siqueira
}

Brasília, DF, 11 de maio de 2004 
Centro de Excelência em Turismo

Gestão e Marketing do Turismo V

\title{
O "PONTO DE FÉ" MÍSTICO-RELIGIOSO COMO ATRATIVIDADE TURÍSTICA
}

\author{
Autor: Gleison de Oliveira Carvalho
}

Orientadora: Deis Elucy Siqueira

Monografia apresentada ao Centro de

Excelência em Turismo da Universidade de

Brasília como requisito parcial para a obtenção do certificado de Especialista em Gestão e Marketing do Turismo.

Brasília, DF, 11 de maio de 2004 
UNIVERSIDADE DE BRASÍLIA

Centro de Excelência em Turismo

Curso de Especialização em Gestão e Marketing do Turismo

\section{O "PONTO DE FÉ" MÍSTICO-RELIGIOSO COMO ATRATIVIDADE TURÍSTICA}

Aluno: Gleison de Oliveira Carvalho

Banca Examinadora:

Orientadora: Deis Elucy Siqueira, Pós-doutorada em Sociologia da Religião

Orientador:

Membro da Banca:

Brasília, DF, 11 de Maio de 2004 
Carvalho, Gleison de Oliveira

O "Ponto de Fé" Místico-Religioso como Atratividade Turística / Gleison de Oliveira Carvalho - Brasília: UnB/CET, 2004. xlii, 42 pág.: il.

I. Monografia (Especialização) - Universidade de Brasília. II. Gestão e Marketing do Turismo. - Centro de excelência em Turismo. Brasília, 2004.

The Point of Faith Mystical \& Religious as Touristic Attractability.

1. Marketing 2. Serviços 3. Turismo Religioso. - Monografia. 
É com grande satisfação que dedico este trabalho aos meus pais, pelo incentivo nos estudos. 
Agradeço aos meus pais e familiares pelo apoio e incentivo, à professora Deis Siqueira, minha orientadora, pelo encorajamento dado, à professora Rosa pelas dicas e idéias, ao meu irmão Gleiton que sempre esteve ao meu lado nos momentos mais difíceis e aos meus amigos Philippe, irmão de todas as horas, pela dedicação em prestar-me ajuda e ao Rafael Tezelli pela ajuda técnica e pelo companheirismo. 


\section{RESUMO}

O Brasil por apresentar um amplo território nacional e um vasto litoral, é visitado por inúmeros turistas todo o ano em suas Regiões e Estados. Conhecido pelas pessoas que o visitam por possuir um clima agradável e propício para o turismo, no entanto, um único segmento pode resumir ao mesmo tempo Fé, Trabalho e Serviço, que é o Turismo Místico-Religioso. Este segmento vem crescendo cada vez mais no Brasil pelo grande número de locais, regiões, cidades e templos voltados para o exercício da fé, de práticas místicas e crenças religiosas. O grande número de pessoas que se deslocam de seus locais de moradia para irem a esses destinos, definem o turismo religioso no Brasil. Assim sendo, a idéia de Ponto de Fé aparece ligada aos valores pessoais de cada turista em relação ao destino e ao motivo das viagens. Por essa razão, receber adequadamente o turista torna-se importante, tanto para manter a sobrevivência e preservação do atrativo, como passa a ser um dever do Estado em garantir o bem-estar das pessoas, no caso, os turistas. Sobre receber bem o turista, o marketing oferece dicas sobre a prestação de serviços que, aplicadas por profissionais, podem gerar satisfações aos turistas em fazer as viagens, gerando divisas para os locais visitados. 


\begin{abstract}
For having a wide nacional territory and a broad coast, Brazil is visited by countless tourists all over the year in its Regions and States. It is known by its visitors for having a pleasent weather propicious for tourism however one segment alone may join faith, work and service that is The Mystical \& Religious Tourism. It is an everyday increasing segment in Brazil because of the great number of places, regions, cities and temples for the faith exercise, mystic practice and religious believes. The great number of people that go from their living places to these destinies define the religious tourism in Brazil. Thus, the idea of faith Point appears linked to the personal values of each tourist related to the destinies and the reasons of the trip. That is why receiving the tourist in a proper way becomes important as much to keep the survival and preservation of the attrctive as to make the people's confort the tourists in this case become a task of state. About receiving well the tourists marketing offers some good ideas on paying services that if applied by a professional may satify the tourists making exchange values for the visited places.
\end{abstract}


2. O CONCEITO DE MARKETING

6. CONCLUSÃO 


\section{1 - INTRODUÇÃO}

O presente trabalho tem por objetivo abordar o segmento de turismo religioso no Brasil, trabalhando o conceito de "Ponto de Fé".

O turismo religioso é considerado como turismo de massa, pois movimenta grande número de pessoas.

O turismo religioso, em sua essência, formado por um valor cultural marcante, substancialmente popular, admite a observação de que não distingue os turistas, entre si, por suas classes sociais. Apenas talvez, por seus locais de origem geográfica e de destinos turísticos, se estrangeiros ou cidadãos brasileiros, somente para a geração de dados e informações estatísticas.

A cidade, a sociedade heterogênea e devidamente organizada, o regime capitalista ocidental, as novas religiosidades, o misticismo, são tópicos a serem abordados de forma estratégica para o trabalho do conceito sobre Ponto de Fé, propondo ao mesmo tempo, uma continuidade nas discussões sobre o turismo religioso no Brasil.

Com base em pesquisas bibliográficas, experiências próprias e observações sobre o assunto em questão, a direção a ser tomada será a de diferenciar o Ponto de Fé dos demais atrativos religiosos, ressaltando os valores pessoais, os motivos que ocasionam os grandes deslocamentos que se caracterizam em turismo e, como conseqüência, devolvem aos atrativos, às regiões, Estados e aos países, além de divisas, empregos, melhor qualidade de vida para a população e, ainda criam para o país uma identidade turística consistente. 
A crescente procura por religiosidade, revela a busca por um bem-estar pessoal e, por vezes, como resposta aos conflitos sociais de naturezas diversas, que, em um contexto global, afetam direta e indiretamente o turismo.

Como forma de contribuição acadêmica, a abordagem sobre O Ponto de Fé Místico-Religioso como Atratividade Turística, sob a forma de pesquisa se faz, por maior discernimento e valorização dos atrativos religiosos em evidência no Brasil, dos demais atrativos criados, especificamente, para fins mercadológicos e exploratórios.

Sobre este aspecto, o marketing propõe o uso de ferramentas que, pelo seu uso estratégico, possibilitam a prestação adequada dos serviços prestados aos turistas em suas viagens. Os conceitos apresentados predefinem as ações que devem ser tomadas durante o planejamento dos serviços ofertados, a fim de satisfazer as necessidades e desejos dos turistas.

Sendo assim, o marketing focalizado no produto, promove uma associação conjunta entre os serviços (bem intangível) e o produto propriamente dito (bem tangível), como parte de um pacote, com a finalidade de satisfazer o turista.

Neste caso, o marketing, através de pesquisas de mercado, salienta o segmento de turismo místico-religioso, como um segmento promissor para as empresas especializadas em serviços turísticos com foco voltado ao atendimento desta clientela específica.

Assim, surge a necessidade de abordar aspectos sobre o ponto de fé e tudo o que envolve sua conceituação, do ponto de vista do turista, do profissional de marketing, do de turismo e dos demais setores envolvidos direta ou indiretamente 
com a área, bem como, algumas formas de movimento religioso que definem os turistas em suas ações e práticas religiosas.

Visto como turismo de massa, o turismo religioso pode ser entendido a partir da observação e da leitura sobre cidade, através de dados meramente quantitativos, considerando apenas os números e não a relação entre as pessoas, onde os lugares por vezes se confundem com as pessoas. Desta forma, apura-se a percepção da idéia sobre o ponto de fé consagrado historicamente, daqueles criados para fins específicos que se justificam através de trabalhos de intensa promoção.

\section{2 - O CONCEITO DE MARKETING}

Sobre os conceitos, pode-se dizer, que fornecem uma estrutura especulativa sobre a ação e o modo de se articular as idéias, as experiências, os resultados da pesquisa, favorecendo ainda se colocar as idéias na prática.

Diante das diversas definições de marketing apresentadas por autores e profissionais da área, destaca-se a de Philip Kotler enraizada na lógica da natureza e do comportamento humanos, segundo ele, "marketing é a atividade humana dirigida para a satisfação das necessidades e desejos, através dos processos de troca". ${ }^{1}$

Através do marketing, espera-se atingir as expectativas do cliente, dando maior abrangência aos processos que envolvem o produto ou serviço, tanto em sua criação como no acompanhamento dos mesmos junto ao cliente.

\footnotetext{
${ }^{1}$ Kotler, 1996, p. 31.
} 
Pode-se entender o conceito de marketing como sendo os esforços para realizar as trocas em potencial, objetivando atingir as necessidades e desejos humanos. Os mercados são portanto, o ponto de partida para os planos e estratégias de marketing.

Os especialistas em marketing devem preocupar-se com as necessidades básicas fundamentais à sobrevivência dos seres humanos, mesmo sabendo que seus produtos estejam mais voltados a atribuir habilidades e em satisfazer as necessidades de ordem elevada de seus consumidores. Por essa percepção, pode-se identificar melhor as possíveis necessidades que uma pessoa esteja procurando satisfazer com a aquisição de um produto e como se dá o processo de mudança dessas necessidades através do tempo.

Para o profissional de marketing, é importante que se avalie o grau de satisfação que seu produto irá proporcionar ao cliente, o desejo que o consumidor têm em realizar a compra de um determinado produto e o que ele almeja ou, o que ele espera atingir com esse produto. $O$ consumidor interessa-se em saber como o mesmo situa-se em relação aos atributos que são mais importantes para ele.

Desta maneira, o marketing procura obter lucros através da satisfação dos clientes, contrapondo-se à idéia de venda única e exclusivamente.

Um bom trabalho de marketing explica o sucesso duradouro na conquista de novos mercados e na fidelidade de seus clientes, pois procura orientá-los para o consumo através do marketing integrado, direcionado para a satisfação do cliente, para só então satisfazer aos desejos da organização.

Do ponto de vista da atividade turística, que cada vez mais vem ganhando espaço no mercado nacional e internacional, Gil Nuno Vaz $^{2}$ utiliza como referência uma definição de marketing turístico de Philip Kotler, segundo a qual: "Marketing

\footnotetext{
${ }^{2}$ Gil Nuno Vaz, 2001, p. 18.
} 
turístico é um conjunto de atividades que facilitam a realização de trocas entre os diversos agentes que atuam, direta ou indiretamente, no mercado de produtos turísticos".

Esta visão ampla, identifica todo o universo que envolve o ambiente mercadológico de trocas e, além disso, apresenta uma noção maior do marketing para o turismo.

Os conceitos formulados por Kotler sobre marketing, são o resultado e a conclusão de um trabalho que deve ser feito anteriormente ao processo de criação de um produto, com o intuito de definir quais as necessidades, desejos e valores que o cliente atribui dentro de um dado mercado, para que a organização possa adaptá-las, a fim de promover as satisfações desejadas, opondo-se, desta forma, aos concorrentes.

Sobre esse aspecto pode-se entender que, a organização concebe suas missões em termos de satisfazer a um conjunto de desejos definidos de um grupo de clientes específicos ou seu mercado alvo e usa a segmentação de mercado para melhor atingir os objetivos da empresa com relação ao que está sendo oferecido e exposto no mercado (como produto) para uma clientela específica.

Com isso a empresa reconhece que a satisfação de desejos requer um ativo programa de pesquisa de marketing para conhecer esses desejos e, deste modo, estará cativando seus clientes levando-os a realizarem futuros negócios com a empresa. A organização reconhece também que todas as atividades de influenciar clientes devem ser colocadas sob um controle integrado de marketing e que deve ser feito um acompanhamento prévio do produto e seu uso, afim de minimizar possíveis problemas.

A empresa ao manter esse foco de satisfazer os clientes, ganha sua lealdade, repetição de negócios e palavras de recomendação. Aspectos que são 
cruciais na satisfação dos objetivos da organização e que devem ser tidas como pontos óbvios na atividade de marketing por parte dos empresários e das organizações.

Devido à amplitude do mercado em potencial, é preciso que se faça uma distinção entre o conceito de marketing e o conceito de venda, para que se possa distinguir as diferenças no trabalho para obtenção dos lucros entre esses dois setores.

Faz-se necessário, por parte de muitos empresários e do público, saber a diferença entre vendas e marketing, com o propósito de direcionar, da melhor forma possível, as necessidades do cliente diante de um produto, como também, informar sobre o melhor método a ser utilizado para a venda de seus produtos.

A venda está direcionada, a princípio, para as necessidades do vendedor. Busca efetuar o maior número de vendas possível, enquanto que o marketing está centrado em atingir as necessidades do comprador através do seu produto e nos diversos itens associados à criação, entrega e o consumo final.

Percebe-se que ambos os setores visam, ao final de seus trabalhos, o lucro, mas usando caminhos opostos. Enquanto a venda procura atingir seus lucros através de um volume crescente de produtos supostamente existentes, o marketing preocupa-se com todo o processo que envolve seu produto, tendo como principal enfoque o cliente, buscando satisfazer desde o valor físico até o valor emocional atribuído a este produto pelo cliente em potencial.

Quem deve dizer aquilo que deverá ser realmente produzido é o cliente. Ou seja, quem irá consumir o produto, quem irá pagar por ele. Então, a partir daí, poderão ser minimizados os gastos das empresas na reformulação dos produtos e estabelece-se, de maneira mais eficaz, a harmonia entre a empresa e seus clientes, através dos produtos e a forma como são trabalhados. 


\subsection{MARKETING DE PRODUTOS}

Para os setores que não visam lucro, o marketing, também, vem crescendo a cada dia. Os clientes têm atualmente muitas opções na hora de decidir por quais serviços e produtos deva escolher. É o caso de faculdades, hospitais, igrejas ou até mesmo de grupos teatrais e artísticos, dentre outros.

Alguns destes setores procuram utilizar-se das técnicas empregadas pelo marketing somente para campanhas ou temporadas com prazos definidos ou por regiões de atuação como é o caso dos grupos de teatro ou artistas. Já outros setores organizacionais como faculdades, hospitais e igrejas, em alguns casos, reconhecem a necessidade de se ter um profissional da área de marketing para direcionar os caminhos a serem tomados pela organização frente aos seus clientes.

O marketing, através da satisfação do cliente com seu produto, torna a venda um ponto secundário a ser atingido, mas não esconde a necessidade de se fazer uma pesquisa de mercado minuciosa, para que seu trabalho final seja consistente e atinja seus objetivos. O cliente sempre será seu foco principal, então torna-se obrigatório conhecer, avaliar e estudar o comportamento do seu cliente a fim de estabelecer um diferencial com relação aos concorrentes.

A percepção das empresas em direcionar seus produtos às necessidades $\mathrm{e}$ desejos dos clientes deu-se de forma gradativa, quando viram que a grande produção de bens de consumo não atingia por completo a satisfação de seus clientes, ocasionando, conseqüentemente, queda nas vendas.

As empresas constataram que os clientes só consumiam aqueles produtos que realmente fossem úteis e adequados a cada ocasião. Então começaram a orientar-se através de pesquisas de mercado, observando mais de perto seus 
clientes, suas necessidades e desejos, como portavam-se os concorrentes diante do mercado em potencial e aquilo que estava sendo ofertado de acordo com a preferência dos clientes.

Sobre este aspecto, Kotler $^{3}$ afirma que o trabalho de marketing deve ser empregado para que se obtenha sucesso e aponta o marketing como sendo o processo pelo qual uma organização desenvolve e ajusta sua oferta às mudanças constantes das necessidades e desejos do mercado.

Por parte das empresas, observou-se então que era preciso ajustar, gradualmente a oferta de seus produtos, buscando adequá-los, precisamente, às necessidades e desejos de cada mercado, observando as mudanças constantes e a dinâmica de cada um com relação ao tempo.

A atenção das empresas, neste momento, voltou-se, de um contexto mais abrangente de mercado, para um mercado específico. Tinha-se anteriormente uma idéia de atingir um número maior de clientes frente a um produto ou serviço, sem considerar a satisfação plena dos clientes. Isso dificultava consideravelmente o estabelecimento da empresa no mercado, pois ocorriam constantes quedas nas vendas, uma vez que os produtos eram fabricados sem levar em consideração as necessidades e desejos dos clientes.

A segmentação desse mercado foi uma saída estratégica e de fundamental importância para as organizações. A partir de então, a empresa pôde identificar o mercado específico de clientes garantindo à ela uma identidade frente ao mercado que atuava.

À partir daí, o próximo passo a ser dado pelas empresas foi o de identificar a maneira como deveriam ser trabalhados os produtos e serviços no mercado em potencial.

\footnotetext{
${ }^{3}$ Kotler, 1996, p.35.
} 
Se acreditassem que o consumidor favoreceria os produtos mais disponíveis e de menor preço do mercado, a produção então teria que estar centrada em larga escala e distribuição. Esta visão de atuação encontra condições propícias de desenvolvimento nos mercados em que a demanda é maior do que a oferta e para as empresas nas quais os custos são elevados, podendo ser reduzidos através de um aumento na produção.

Se fosse identificada a necessidade de se trabalhar o produto, teriam então que chamar a atenção dos consumidores apresentando maior qualidade e inovações dos produtos dentro do mercado. Estariam assumindo em correr o risco de se não acompanharem as mudanças de desejos dos mercados, poderiam decretar a falência da empresa.

Com o enfoque de trabalho para as vendas, as empresas estariam direcionadas para a crença de que o cliente estará sempre consumindo o que as organizações produzem e não aquilo que o mercado deseja consumir no momento. Pensa-se em criar, nesta visão, uma necessidade no cliente de que ele, por conta própria, não irá comprar o bastante.

Se a empresa chegasse a conclusão de que seu foco de trabalho deveria ser voltado para o marketing, o interesse da organização estaria em determinar as necessidades e desejos do mercado, a fim de satisfazê-los de modo mais sublime que os concorrentes, tendo o lucro como uma conseqüência dos esforços dessa atividade. Mas antes, conhecer o mercado através de pesquisas com os clientes e analisando a forma de atuação da concorrência, seus pontos fortes e seus pontos fracos.

Porém, dando enfoque no marketing social, as organizações podem determinar, além das necessidades e desejos e interesses do mercado, 
satisfazendo-os mais eficientemente, fixar na consciência dos clientes, que tanto a empresa quanto seus consumidores possuem os mesmos pontos de vista, valores e atitudes, dentro do contexto sócio-ambiental em que estão inseridos.

Os consumidores sabem distinguir o comportamento de cada empresa no mercado, logo, eles as aprovam ou reprovam dependendo do comportamento de cada empresa em seu papel social. Neste enfoque, deve-se saber que o cliente não está preocupado somente em atender suas necessidades e desejos, mas em fazer com que as necessidades gerais do ambiente em que se encontra sejam consideradas e atendidas pelas empresas.

\section{2 - MARKETING DE SERVIÇOS}

São muitas as definições de serviço, pois são diversos os setores econômicos que podem ser empregados. A cada definição pode ser considerado um ponto de vista dos trabalhos desenvolvidos em cada segmento empresarial, juntamente com a percepção do consumidor.

A definição de Stanton ${ }^{4}$ abrange melhor os trabalhos realizados em turismo:

Serviços são atividades intangíveis, separadamente identificáveis que fornecem satisfações desejadas quando colocados aos consumidores e/ou usuários industriais e que não são necessariamente ligados a venda de um produto ou outro serviço.

As características dos serviços foram, durante algum tempo, muito questionadas, pois não se tinha uma visão genérica dos benefícios proporcionados, tanto para os clientes, como para os empresários e fornecedores, em sua área de atuação. 
Sabe-se, pois, que os serviços possuem características próprias diante do consumidor.

Intangibilidade - os serviços não passam por nenhum dos sentidos do consumidor antes de serem adquiridos. Para comprá-los, o consumidor precisa depositar certo grau de confiança no fornecedor, que por sua vez, para dispor o serviço, deve não somente fazer uma descrição das características do serviço, mas dar ênfase aos benefícios do produto. Ou ainda, dar nomes de marcas aos serviços ou trabalhar a imagem de pessoas públicas, vinculando-as aos serviços, para credibilizar os serviços e aumentar a confiança do consumidor. Por este trabalho, o fornecedor procura tornar tangível os serviços.

Inseparabilidade - assegura que um serviço está obrigatoriamente ligado a seus fornecedores, sendo pessoas ou máquinas. Para o caso de pessoas, o fornecimento dos serviços com relação ao tempo, pode ser caracterizado ou moldado para cada cliente, no esclarecimento de dúvidas, queixas, pedidos, etc. No caso de máquinas, há uma padronização de tempo e de qualidade no fornecimento de um serviço, desconsiderando o diálogo e um atendimento personalizado. Neste último, subentende-se que o cliente já tenha um conhecimento prévio deste tipo de fornecimento de serviço.

Variabilidade - depende de cada fornecedor, do local onde será fornecido e também do período em que se encontrará disponível o serviço. Os consumidores reconhecem esta dinâmica da variabilidade dos serviços e geralmente procuram informações a respeito com outras pessoas antes de formalizarem a escolha de um prestador. Neste momento, o fornecedor deve procurar garantir qualidade nos serviços, com funcionários selecionados e treinados para um contato direto com o cliente, trabalhando a satisfação do consumidor através de um acompanhamento,

\footnotetext{
${ }^{4}$ Stanton, 1974, p. 545, apud Ana Akemi Ikeda, 1995, p. 91
} 
coletando sugestões, anotando críticas e reclamações, para identificar e corrigir erros.

Perecibilidade - os serviços não podem ser estocados ou armazenados como alguns produtos. Para que um serviço seja disponibilizado, há um gasto anterior que procura reverter o capital empregado e obter uma certa margem de lucro. O serviço não sendo consumido, declara o prejuízo de investimento, que jamais poderá ser recoberto.

Em turismo, os serviços complementam-se naturalmente, entre aspectos tangíveis e intangíveis, podendo ser comprados e consumidos ao mesmo tempo pelos clientes. A tangibilidade desses serviços é caracterizada por atributos físicos e a intangibilidade, por benefícios ofertados ao cliente e satisfações proporcionadas pelos serviços. Embora esta distinção seja feita, há momentos em que um produto é confundido com um serviço, como em um restaurante. Em uma refeição, encontram-se os produtos alimentícios, de caráter físico, ou seja, produto tangível, preparada e servida por um serviço, de caráter imaterial, produto intangível. Grande parte dos produtos turísticos, para serem consumidos, precisam ser assistidos, desde a preparação, até o fim de seu consumo, por um serviço.

Os componentes de um serviço turístico podem ser classificados em quatro níveis dos atributos mais considerados pelos clientes e pela concorrência, são eles: básicos, esperados, desejados e inesperados.

Os atributos básicos são aqueles mínimos que um cliente pode encontrar, entre aspectos tangíveis e intangíveis, para se realizar um negócio. As empresas que apresentam somente atributos básicos a seus clientes são consideradas ruins caso os concorrentes estejam oferecendo outros de nível mais elevado. 
Os atributos esperados são aqueles que o cliente já considera fazer parte do negócio. Para eles, a empresa que oferece apenas atributos básicos e esperados, é considerada satisfatória.

Os atributos desejados são os que o cliente apreciaria se fossem ofertados e inclusos no negócio, embora não os espere. A empresa passa a ser beneficiada pela procura dos clientes se realmente estiver realizando melhor trabalho que os concorrentes.

Os atributos inesperados são aqueles que surpreendem e adicionam valor para o cliente, indo além do que o consumidor espera. Àqueles que fazem um bom trabalho em surpreender o cliente, têm a preferência. $O$ cliente indica a empresa, ou fornecedor, para outros, através da propaganda boca a boca. É importante que a organização saiba que, após algum tempo, estes atributos se tornarão esperados pelo cliente. A empresa deve então investir em pesquisas a procura de novos atributos inesperados, para que continue a surpreender 0 cliente. Desta forma também estará limitando a atuação da concorrência.

A importância de uma pesquisa bem elaborada no setor de serviços é a garantia da boa imagem da marca de uma empresa, da plena satisfação dos clientes e o orgulho dos funcionários, sendo também, um pesadelo para os concorrentes despreparados.

Mas os trabalhos de coleta de dados e informações a respeito da atuação da concorrência no mercado, por parte das empresas fornecedoras de serviços, são recentes. Há também, a ausência de dados específicos, o que dificulta o trabalho de marketing no acompanhamento e gerenciamento dos serviços ao cliente. 
Para que tais atividades desenvolvam-se em perfeita sintonia, faz-se necessário que as unidades produtivas de bens e serviços turísticos adeqüem-se aos fatores de produção, para otimizar o volume da oferta.

A adequação das unidades produtivas de bens e serviços turísticos aos fatores de produção, explica-se da seguinte forma: Os fatores de produção, em conjunto, formam a unidade do produto turístico, que necessita basicamente dos serviços para chegarem ao cliente. No mercado são expressos na forma de bens e serviços, que serão consumidos de acordo com as variáveis da demanda.

Os principais atores desta dinâmica atividade mercadológica de desenvolvimento do turismo, seja em um país, uma região ou município, são as organizações públicas e privadas, que controlam tanto a venda como a produção de bens e serviços.

A importância do Bacharel em Turismo e sua proposta de trabalho é justamente fazer com que haja uma interação, um trabalho em conjunto entre a organização pública e privada, de maneira que todos possam usufruir dos benefícios que o turismo oferece, tendo como foco de ação o trabalho de marketing.

No turismo, os serviços estão em uma escala proporcional maior que os produtos ofertados à demanda. Pode-se imaginar que para cada produto produzido ou ofertado por uma empresa aos clientes são agregados inúmeros serviços, até o consumo final de cada produto.

A importância dos serviços agregados aos produtos pode ser entendida como o trabalho de um joalheiro em um diamante bruto encontrado na natureza. Ele lapida, modela e dá forma ao diamante, atribuindo beleza e valor, de modo a causar impacto aos olhos do cliente. Sem o serviço, fica difícil que um produto em si, atinja a eficácia em atender plenamente as necessidades e desejos do cliente. 


\section{3 - RELIGIÃO E MISTICISMO}

Tendo o turismo religioso como base para o início de estudos acadêmicos, aos poucos, pode-se observar que, sua importância, está intimamente ligada à vida particular das pessoas que viajam pelo mundo a lugares místico-religiosos, a procura de descanso e conforto espiritual.

E, como se a busca pelo sagrado, o celestial e grandioso ser criador de todas as coisas levasse a todos a adotar uma postura de religiosidade como condição vital, misticismo e religião então separam-se por modo de definição.

Embora se possa entender intuitivamente o que venha a ser definido como religião, Rubem Alves explica antes que, a religião aparece como uma "teia de símbolos, rede de desejos, confissão da espera, horizonte dos horizontes, a mais fantástica e pretenciosa tentativa de transubstanciar a natureza" ${ }^{\text {". }}$.

De acordo com essa definição, pode-se entender que as pessoas procuram criar uma linguagem para aquilo que elas não podem ver, mas somente ser sentido sob a forma emocional. Em nada pertencendo a fatos e caracteres excepcionais.

Para Rubem Alves: "A religião nasce com o poder que os homens têm de dar nomes às coisas, fazendo uma discriminação entre coisas de importância secundária e coisas nas quais seu destino, sua vida e sua morte se dependuram"

\footnotetext{
${ }^{5}$ Alves, 1984 p. 22

${ }^{6}$ idem, p. 24
} 
Assim, nessa abordagem, os objetos recebem nomes e usos conforme cada tipo e são também classificados como prioritários, dependendo do grau de importância e da diferença que possam fazer para a sobrevivência do homem. Desse modo, quando o homem se reporta a algum personagem de sua religiosidade, ele a produz, de alguma forma, em seu imaginário.

Embora seja entendido, que a religião não parta somente do imaginário popular, ela sugere valores sentimentais de amor, integridade e poder pela fé, que por vezes, são distorcidos pela ciência. É o que destaca Rubem Alves, por um comentário de Durkheim: "Diz-se que a ciência, em princípio, nega a religião. Mas a religião existe. Constitui-se num sistema de fatos dados. Em uma palavra: ela é uma realidade. Como poderia a ciência negar tal realidade?"7.

Esse reforço afirmativo sobre a existência da religião, embora a ciência diga e tente comprovar o oposto, permite admitir que, a religião exerce um papel importante na sociedade, observando-se o segmento de turismo religioso e, para a própria ciência que a toma como ponto de partida para suas pesquisas, tentando dar respostas às perguntas como: De onde viemos? Qual a verdadeira origem da vida? Por que somos desta ou daquela forma? E etc.

A visão de mundo sob os aspectos materiais e imateriais dá às pessoas, motivos e condições para a sobrevivência da vida social. É esse o propósito de investigação de Durkheim sobre investigação da religião.

Já sobre o misticismo, observa-se que há uma real atitude por parte dos místicos uns com os outros e com o próximo, sob uma busca comum em relação ao sagrado. 
Segundo Deis Siqueira: "misticismo é definido como a atitude humana que visa à união das pessoas com as forças sagradas, transcendentais, o mistério fascinante". 8

Esse conceito revela a busca do homem pelo ser divino que se materializa nos animais, nas pessoas, nos elementos e fenômenos da natureza, nos fatos e acontecimentos inexplicáveis, que acompanham o homem desde sua origem mais primitiva.

Atualmente, o que se vê é uma exposição maior do misticismo, e de identificação pessoal de novos adeptos, que buscam novas experiências espirituais. Talvez, essas dados sejam mais comuns aos habitantes de BrasíliaDF, que é considerada uma cidade mística por natureza e história e, ainda mais, para as pessoas que moram na cidade de Alto Paraíso de Goiás, localizado a aproximadamente $230 \mathrm{Km}$ de Brasília, marcado pelo grande número de adeptos místico-esotéricos, tida como paraíso e que recebe, constantemente, a visita de turistas pertencentes a esse segmento.

Em Brasília cidade planejada para ser a sede do Governo Federal e centro das decisões políticas do país, Segundo Deis Siqueira, "religiões tradicionais, tais como o budismo e outras religiões centradas nas Escrituras Védicas, estão sendo revividas no Ocidente e particularmente em Brasília, dentro da perspectiva de uma nova religiosidade e de um novo estilo de vida, que se diferenciem das religiões ocidentais tradicionais cristãs"9.

Brasília surge então, sob esse ponto de vista, como uma cidade moldada pelos aspectos místico-religiosos e de grande potencial turístico a ser explorado.

\footnotetext{
${ }^{7}$ Durkheim, apud idibem, p. 58

${ }^{8}$ Siqueira, 2003 p. 16.
} 
Assim, em terreno fértil, surgem outros "movimentos religiosos" ou extensões religiosas advindas das religiões tradicionais, a citar: o Cristianismo, o Judaísmo, o Budismo, o Islamismo, Confucionismo, Taoísmo, Xintoísmo e o Bramanismo (Hinduísmo).

Há também que se ressaltar que as pessoas que se dizem não pertencentes a nenhuma das religiões tradicionalmente conhecidas, mas que em algum momento de suas vidas participaram de algumas delas, em sua grande maioria são definidas por Deis Siqueira como pessoas que atualmente estão:

"construindo sua religião numa espécie de bricolage, compondo, por conta própria, doutrinas, práticas, rituais, que vão sendo incorporados a partir de vivências ou experiências em vários desses grupos místicoesotéricos e com as práticas não convencionais ou alternativas de cura, de auto conhecimento, em boa medida associados aos valores e visões de mundo desses grupos" ${ }^{\prime 10}$.

Vale destacar os movimentos das massas que se dirigem aos templos supremos da fé ou a algum ponto de devoção de crenças, como os templos secundários, igrejas, sinagogas, mesquitas, etc.

O Cristianismo é a religião mais abrangente do mundo, contando mais de 1,7 bilhão de adeptos distribuídos por todo o planeta ${ }^{11}$. No Brasil é a religião predominante, de acordo com o último censo, e os fiéis, sempre à procura do perdão, acabam por realizar diversas festas de Santos Católicos para poderem pagar suas penitências.

\footnotetext{
${ }^{9}$ Idem, p. 40

${ }^{10}$ idbidem, p. 40

${ }^{11}$ ONU, http://www.onu.org, acesso em 12 de Janeiro de 2004.
} 
O Islamismo, importante religião mundial (a população muçulmana é estimada em mais de 935 milhões $^{12}$, originária da península da Arábia e baseada nos ensinamentos de Maomé (570-632), chamado o Profeta. Esta religião, segundo os dados da ONU, é a que mais cresce no mundo. Devido a uma prática obrigatória para todos os fiéis da religião, pode-se observar um dos maiores movimentos de peregrinação do mundo, pois todo fiel deve, pelo menos uma vez na vida, visitar a cidade de Meca, na Arábia Saudita.

Há também, os chamados novos movimentos religiosos, sobre eles, destaca-se o movimento New Age, definido por Deis Siqueira, "como um conglomerado de tendências que não teria textos sagrados ou líderes, nem organização fechada ou estrita nem dogmas". ${ }^{13}$ De certa forma, são tidos como movimentos não litúrgicos pela ausência de escrituras sacramentais ou qualquer espécie de liderança organizada e predefinida.

Ainda sobre as diversificadas atividades do movimento New Age que atrai mais e mais adeptos a essa visão de mundo, Deis Siqueira agrupa as técnicas que compreendem esses grupos pelas práticas de "curandeirismo, geomancia, cartomancia e astrologia pertencem ao repertório tradicional de cura e conselhos práticos das sociedades pré-industriais"14, retomando, atualmente, sua popularidade.

Entendidas como um novo estilo de vida, as novas religiosidades por grupos místico-religiosos, remontam uma forma de evolução pessoal, através das realizações pessoais sobre a divinização, pela continuidade das experiências vivenciadas, que ajudam a definir caminhos próprios e visões de mundo material e

\footnotetext{
${ }^{12}$ ONU, http://www.onu.org, acesso em 12 de Janeiro de 2004.

13 op. cit. Siqueira, p. 19.

${ }^{14}$ Idibem, p. 34
} 
imaterial, entendidas pela interpretação dos estudos de Deis Siqueira sobre a psicologização das religiões ${ }^{15}$.

Como mostrado anteriormente, sobre a importância de se abordar aspectos desse segmento, composto por um público extremamente significativo, vale lembrar que, à medida em que são descobertos novos nichos de mercado, que por sua vez é composto de pessoas, novas exigências de clientela são percebidas pelos produtos e serviços dispostos para consumo. No caso específico do turismo, isso significa que todo o trade turístico como: bares, restaurantes, hotéis e pousadas, agências e operadoras de viagem, companhias aéreas, dentre outros atores envolvidos, devem redirecionar seus esforços organizacionais para atender a essa nova demanda. O motivo é simples, garantir a sobrevivência das empresas num mercado altamente competitivo.

A religião, de certa forma, está presente na vida das pessoas há séculos, através de liturgias e dogmas, funcionando como um norteador, embora, com o passar dos tempos, venha sofrendo mudanças singelas para acompanhar as novas inclinações da sociedade na expressão de suas crenças.

Por essa razão, tornam-se cada vez mais freqüentes o desenvolvimento de projetos voltados a esse tipo de segmento dentro do turismo. O chamado turismo místico-religioso tem mantido fluxo constante de turistas pelas diversas localidades regiões do Brasil.

Pelo tipo de religiosidade praticada no Brasil, movimento de massas, podese constatar que o conceito que mais se aproxima, é o de Durkheim ${ }^{16}$ :

\footnotetext{
15 ibidem, p. 93

${ }^{16}$ Durkheim, apud, Bocock e Thompson, 1985, p. 42
} 
A religião é algo eminentemente social. As representações religiosas são representações coletivas que expressam realidades coletivas; os ritos são de uma maneira de agir que ocorre quando os grupos se reúnem, sendo destinados a estimular, manter ou recriar certos estados mentais nesses grupos.

O grande motivo de se entender a religião e os cultos místicos em prática nos dias de hoje, ocorre para facilitar o entendimento de que a sociedade caminha conforme seus valores de coletividade, como se possuísse uma identidade própria, e ela possui. Seus órgãos e instituições podem ser vistos como membros de um corpo humano em toda sua complexidade.

E quando se fala em religião ou misticismo ou qualquer outra forma de crença, estabelecem-se, logo em seguida, os valores pessoais, as formas de cultura existentes conquistas materiais. Sendo esta última, a mais próxima e passível de realização, ou não, que leva o homem a buscar complemento ou razão para sua existência. Busca-se alcançar o intangível, resgatar seus antigos valores, deixados de lado pela filosofia do materialismo, então, mudam-se os hábitos e a maneira de pensar sobre os fatos da vida cotidiana, de modo que a vida passe a fazer sentido.

Assim, a religião floresce no homem de acordo com o poder de imaginação que cria sobre as coisas. O mundo material é e sempre será como a construção do imaginário dos homens, o poder de idealização de seus sonhos. A religião funciona como uma busca pelo aperfeiçoamento da alma e uma relação mais possível com o próximo. 


\section{4 - O PONTO DE FÉ}

O Ponto de Fé ou Ponto de Atração de Fé é um ponto turístico criado a partir do imaginário popular ou de uma relação religiosa institucionalizada, que motiva as pessoas a buscá-lo através do turismo.

O turismo sempre se fez valer pelas atratividades naturais ou construídas, e até mesmo transformadas pelo homem. No caso, O Ponto de Fé é uma nova modalidade de atrativo, onde as pessoas não irão por motivo de diversão ou de lazer e sim, para uma busca espiritual, independente de suas crenças religiosas.

As religiões de massa sempre proporcionaram "espetáculos" de movimento em busca desses pontos. Alguns desses pontos de fé, confundem-se com pontos criados pelo homem, mas a relação entre o homem, que busca o ponto e Deus (Ser Supremo), não está inserido neste tipo de construção, e sim, em uma relação transcendental.

As pessoas, em muitos casos, não criam o Ponto de Fé intencionalmente, pois o mesmo é fruto de uma massificação do lugar, não estando reservado a uma cidade ou a uma igreja específica, como exemplos. Pois o Ponto de Fé, pode ser intangível, como um local de aparições, como Medjugore, ex-lugoslavia ou um caminho, como o de Santiago de Compostela. Para muitas religiões existem manifestações que são explicadas apenas por meio da fé, sem o auxílio da ciência, dando o caráter de intangibilidade do ponto. 


\subsection{FORMAS DE MOVIMENTO RELIGIOSO}

No Brasil, o movimento religioso católico define o turismo religioso em três formas e objetivos, distinguidos pelos fiéis, que são: as romarias, as peregrinações e as penitências.

As romarias são feitas somente com o intuito de viajar a lugares sagrados, por vontade própria e em muitos casos, sem objetivar recompensas materiais ou espirituais. Os romeiros comumente perfazem todo o roteiro turístico da localidade que esteja em algum momento ligado à fé e devoção, como obras de arte sacra e altares de igrejas de séculos passados ${ }^{17}$.

As peregrinações podem ser entendidas quando as pessoas vão visitar lugares sagrados para cumprir promessas em devoção a algum santo e por ter alcançado ou para alcançar alguma graça. Pode-se identificar mais facilmente um peregrino, através de seus hábitos dirigidos a seu santo de devoção. Os pedidos para alcançar uma graça, geralmente são feitos quando o cristão visita um local de retiro espiritual pela primeira vez, sentindo que a passagem por aquele local tenha um significado religioso, como um chamado de Deus ${ }^{18}$.

As penitências são as expressões mais grandiosas de humildade por parte dos fiéis em admiração a um santo. Busca-se, através das penitências, a redenção dos pecados e culpas cometidas. As penitências são, na maioria das vezes, aconselhadas por líderes religiosos, mas podem também partir dos próprios fiéis, que as dirigem a locais sagrados em sentido de arrependimento.

A cada ano, vem crescendo o número de turistas que, por motivos religiosos, visitam cidades, estados e até vão a outros países como em Portugal, na cidade de Fátima. Através da religião exprime-se também a cultura de um

\footnotetext{
${ }^{17}$ Siqueira, Religosidade e Turismo em Brasília, 2003, p. 02
} 
povo, atuando como um agente social, garantindo proteção. A religião ajuda a resgatar antigos valores e a coibir atos anti-sociais que possam comprometer 0 futuro dos indivíduos.

Embora os dados mais recentes divulgados pelo Censo 2000 do IBGE (Instituto Brasileiro de Geografia e Estatística) demonstrem mudanças no perfil religioso do País, o turismo religioso tem crescido vertiginosamente. Pesquisas sobre os impactos econômicos do turismo religioso no Brasil, ainda que pouco expressivas e insuficientes, revelam que esse segmento revigora a economia local sob a ação das adaptações de equipamentos de hospedagens, terceirização de serviços, comércio e restaurantes, entretenimento, etc., salientando a sua importância para a região. Pode-se inferir então que, independentemente de qualquer religião, a procura por ajudas espirituais tem sido notável e constatada pela prática do turismo religioso.

"Segundo o IBGE, 11 milhões se converteram à religião evangélica nos últimos dez anos. É um aumento de 70\%. A umbanda e o candomblé estão desaparecendo, com apenas $0,3 \%$ dos brasileiros. A igreja católica sofreu uma queda recorde, perdeu 10\% dos fiéis, agora são 73,8\%. A menor proporção de católicos está no Rio de Janeiro, são pouco mais de oito milhões de pessoas. Os evangélicos estão aumentando, já representam $20 \%$ da população do estado do Rio, com três milhões de fiéis. No estado, há 400 mil espíritas e 200 mil seguidores de umbanda e do candomblé. Mas o Rio de Janeiro também tem o maior número de brasileiros que se dizem "sem religião". São 2,2 milhões de pessoas. São tantos os "sem religião" que ficaram em terceira posição, depois de católicos e evangélicos, 12.330 milhões de brasileiros". ${ }^{19}$

As mudanças no perfil religioso do Brasil foram diagnosticadas, ainda que muitos fiéis não concordem com os resultados divulgados pelo Censo 2000 do IBGE.

\footnotetext{
${ }^{18}$ Idibem, p. 02
} 
Em virtude da enorme evasão de fiéis, a igreja católica toma uma nova postura, criando os movimentos carismáticos, os movimentos pastorais, investindo mais em festas de santos padroeiros, com o surgimento de padres cantores, no lançamento de campanhas, serestas para casais, dentre outros eventos, fazendo com que os católicos tornem-se mais fervorosos e mais participantes na igreja.

Os números apontados pelo Censo 2000 do IBGE revelam que há, em todas as religiões, os chamados "fiéis modistas", que acompanham por partes e por um determinado período os tempos litúrgicos de cada religião.

\section{2 - PONTO DE FÉ TANGíVEL}

No caso específico do Brasil, observa-se um maior número de pontos de fé de caráter tangível. Sendo eles, em sua maioria, cidades que se apresentam como ponto de fé pela sua arquitetura, no caso, as igrejas, por festas de padroeiros ou pelas confluências de energias, no caso dos místicos.

As cidades que se destacam por suas igrejas, também remontam um caráter histórico, bastante influenciado por estilos de época, mas não perdem sua identidade com a fé, atraindo romeiros, peregrinos e fiéis, sendo estes os verdadeiros turistas de fé. Dentre elas destacamos: Aparecida, em São Paulo,

Ouro Preto e Congonhas, em Minas Gerais, Bom Jesus da Lapa, na Bahia, etc. Não se deve esquecer as outras formas religiosas com suas arquiteturas próprias. Exemplificando: as seitas de Alto Paraíso de Goiás, como a do Raio Violeta de Saint German e em Pirenópolis, também no estado de Goiás, com a Bolha.

Existem também, as cidades que atraem os turistas por conta de suas festas religiosas. Muitas festas referem-se aos dias reservados dentro do

\footnotetext{
${ }^{19}$ IBGE, Censo 2000, apud http://www.ibge.gov.br/censo, acesso em 12 de Janeiro de 2004.
} 
calendário aos santos e também, referente a algum tipo de milagre ou aparição. Essas cidades são, de certa forma, as mais visadas por conta de uma manifestação mais fervorosa por parte dos fiéis em relação ao santo de devoção. Pode-se citar O Círio de Nazaré, em Belém do Pará, dia 12 de outubro, Dia de Nossa Senhora de Aparecida e novamente, a cidade de Aparecida, em São Paulo. As outras formas religiosas possuem festas pouco divulgadas, que não merecem ressalva.

Existem outras cidades que possuem pontos atípicos. Cachoeira Paulista, em São Paulo, com o movimento Canção Nova, que atrai jovens e adultos de todo país, sem uma data específica, sendo o Carnaval, a Semana Santa e o acampamento dos músicos, em outubro, seus maiores fluxos. Juazeiro do Norte, no Ceará, muito conhecido por causa do Padre Cícero que, por seu envolvimento com a política, morreu excomungado pela igreja católica, não impedindo uma devoção por parte do sertanejo nordestino em torno de sua figura, proporcionando verdadeiro espetáculo de romarias, que fez com que a igreja revisse seu processo de excomunhão. E Guaratinguetá, em São Paulo, por conta das pílulas milagrosas do beato Frei Galvão, tais pílulas e a cidade, ficaram conhecidas após a beatificação do Frei Galvão.

Em outros países, assim como em outras religiões, pode-se observar outros pontos de fé e outras manifestações, trabalhando apenas as religiões de massa, que são as de maior número de adeptos, o cristianismo e o islamismo.

$\mathrm{Na}$ região de Jerusalém estão presentes templos religiosos de três religiões: judaísmo, cristianismo e islamismo. Para o cristianismo, a importância do ponto, se refere ao local de nascimento e morte de Jesus Cristo, sendo um excelente atrativo de fé para todos os cristãos do mundo. Logo, para as outras religiões, a região se designa apenas por possuírem templos religiosos, tais como: a Mesquita do Domo da Rocha, para os islâmicos, que acreditam que a mesquita fica sobre a rocha onde Maome pisou pela última vez antes de subir ao paraíso e 
o Muro das Lamentações, para os judeus, a última parte restante do templo construído por Salomão.

Roma, mais precisamente, o Vaticano, pode ser considerado o ponto de fé máximo da religião católica, por ser a residência e a sede da Igreja Católica Apostólica Romana.

A cidade de Meca, na Arábia Saudita é um ponto obrigatório para todo seguidor do islamismo. Pelo menos uma vez na vida, o fiel deve conhecer a cidade e tocar a pedra da Caaba, onde se encontram os restos mortais do profeta Maomé. Todo ano ocorrem peregrinações onde boa parte do mundo muçulmano se manifesta através de uma caminhada em direção a cidade, que por muitas vezes acaba em morte, causada por diversos fatores, entre eles, fome, doenças e pisoteio.

\section{3 - PONTO DE FÉ INTANGÍVEL}

A característica de intangibilidade do Ponto de Fé está relacionada com valor imaterial e intuitivo empregado pelas pessoas sobre as entidades divinas e das sensações de proximidade do ser cultuado, além de práticas místicas que proporcionam sensações agradáveis entre os componentes de um mesmo grupo.

Quando a visita a um determinado Ponto de Fé se faz pelo fato de se cumprir uma promessa por uma graça alcançada no mundo material, a intangibilidade ocorre pelo sentimento de uma missão que se cumpre, como tentativa de estabelecer um contato entre os dois pólos, o material e o imaterial.

Santiago de Compostela, na Espanha, é um exemplo, onde a visita à cidade só é consagrada, por meio de uma peregrinação, ficando conhecida como Caminho de Santiago. Esta peregrinação é o verdadeiro ponto de fé, pois a 
peregrinação começa na cidade de St. Jean Piet-de-Port, no sul da França, e após 750 quilômetros, em cerca de 30 dias, os peregrinos chegam à cidade. É importante ressaltar que existem outros caminhos para se chegar à cidade. Este é um exemplo de ponto de fé intangível, pois não se refere à cidade, mas sim ao ato de se percorrer o caminho até a cidade.

A cidade de Belém, no estado do Pará, também atrai turistas desse seguimento por conta da Festa do Círio de Nazaré, que se enquadra perfeitamente neste exemplo de intangibilidade.

Não se trata aqui, de mencionar pontos de turismo religioso, mas chamar a atenção pela força da fé do turista que escolhe determinado destino. Levando em conta apenas a sua fé ou sua tentativa de buscá-la.

\section{5 - TURISMO RELIGIOSO NO BRASIL}

Dentre os segmentos turísticos específicos como: turismo de eventos, de saúde, gastronômico, histórico, de lazer, dentre outros, o que mais tem chamado atenção, devido ao grande número de pessoas que movimenta, é o turismo religioso.

Tabela I - Propensão a viajar e a propensão por motivos Religiosos do total das viagens feitas. ${ }^{20}$

\begin{tabular}{|l|l|l|}
\hline \multicolumn{1}{|c|}{ Classe } & \multicolumn{1}{|c|}{ Propensão a viajar } & \multicolumn{1}{c|}{$\begin{array}{c}\text { Propensão a viajar por } \\
\text { motivos Religiosos }\end{array}$} \\
\hline 0 a 4 SM & 24,0 & 3,2 \\
\hline 4 a 15 SM & 38,3 & 1,4 \\
\hline Mais de 15 SM & 54,8 & 0,6 \\
\hline Total & 24,0 & 2,2 \\
\hline
\end{tabular}

*População Expandida; na População amostrada a propensão é de 36,4\%.

FIPE 
De acordo com os dados da pesquisa FIPE, 24\% da população brasileira realiza pelo menos uma viagem doméstica a cada ano, sendo o motivo "Religião" representado por 2,2\% desse total. De acordo com a tabela I acima, pode-se observar que há uma motivação maior por parte dos turistas de baixa renda, ao passo em que ocorre uma diminuição dos turistas que viajam pelo mesmo motivo à medida em que demonstram uma renda maior.

Segundo dados obtidos do site Marketing.com.br, o mercado religioso no Brasil, possui um público consumidor de 26 milhões de pessoas, de todas as classes sociais, que movimento cerca de $\mathrm{R} \$ 3$ bilhões por ano. ${ }^{21}$

Além dos motivos que levam o turista deste segmento a lugares santos para comemorações de datas, a lugares que manifestaram aparições de santos ou milagres constatados ou não pelo Vaticano (sede oficial do Papa), o turismo religioso pode levar o turista a praticar outras modalidades turísticas, de acordo com a potencialidade de cada região visitada, com diversos outros atrativos, como pontos históricos, museus, cidades históricas, manifestações culturais, eventos e etc.

O turismo religioso expressa o grande sentimento de fé e caridade dos brasileiros por meio das romarias e peregrinações a diversos lugares religiosos, podendo ocorrer de forma organizada ou individual, programadas ou definidas pelos próprios turistas de acordo com a motivação religiosa e os dogmas de cada um.

No turismo religioso, no Brasil, destacam-se como principais receptores os estados, do Ceará (33,7\%); São Paulo (19,3\%); Bahia (14,3\%) e Rio de Janeiro $(12,4 \%)$, acumulando quase $80 \%$ do total dessas viagens. ${ }^{22}$

\footnotetext{
${ }^{20}$ http://www.sindetur.com.br/turismo_em_numeros/estatistica_13.pdf. Acesso em 19, mar, 2004.

${ }^{21} \mathrm{http} / / /$ www.marketing.com.br, acesso em 03 de março de 2004.

22 http://www.sindetur.com.br/turismo_em_numeros/estatistica_13.pdf. Acesso em 19, mar, 2004.
} 
As potencialidades de determinados Estados e Regiões do Brasil, conforme demonstrado, revelam a importância de se criar projetos que preencham de forma substancial, as necessidades específicas do segmento religioso, como forma de acompanhamento de seu crescimento junto aos turistas.

Os números indicam que os valores sociais de uma região para outra podem ser tratados como indícios de um mercado em expansão e pouco explorado, se comparados com destinos ainda pouco expressivos e que não aparecem nas pesquisas e nos dados estatísticos de órgãos de referência.

\section{1 - O SENSO DE CIDADE E O TURISMO RELIGIOSO}

A noção de cidade, proposta por diversas análises, se afasta dos referenciais sociais, por uma simples leitura de dados quantitativos, onde o que se considera são apenas números e não a relação entre seus habitantes. A cidade é mais que um aglomerado de edificações e sim um conjunto intrincado de manifestações sociais e culturais. Os lugares, devem, se confundir com os seus habitantes.

Através dos estudos históricos, pode-se compreender o movimento da sociedade na construção dos espaços na cidade. Esses movimentos construtores de espaço são, muitas vezes, de cunho cultural. A cidade pode ser entendida como "um espaço que traduz uma certa peculiaridade de lugar construído pelas experiências e pensamentos de homens, indicando que o universal está nas ações dos homens." ${ }^{23}$ Para Deusdedith Junior ${ }^{24}$, outros sinais surgem da cidade quando se busca nela as coisas triviais, percebendo-a deste modo consiste em acompanhar seu movimento.

\footnotetext{
${ }^{23}$ Rodrigues, 1996, p. 58
} 
A cidade é palco de diversas manifestações culturais, dentre elas, a místico-religiosa, onde seus personagens desempenham papel fundamental na massificação do turismo. O turismo também é considerado uma dessas manifestações, e de acordo com Beni: "os recursos turísticos culturais são, pois, os produtos das manifestações culturais". ${ }^{25}$ Como Beni ressalta, pode-se aliar as práticas religiosas às práticas turísticas, e usar a cidade como palco.

A cidade de Aparecida, em São Paulo, é um exemplo claro da união da prática religiosa católica com o turismo convencional ou doméstico. Mas observase que não se trata de um exemplo isolado, existindo outras cidades, como Congonhas em Minas Gerais, outras práticas religiosas e outras práticas turísticas.

Diante desses fatores, pode-se aglutiná-los e criar uma nova modalidade, chamada Ponto de Atração de Fé. Diferentemente dos atrativos naturais e dos construídos pelo homem, pois trata-se de uma manifestação cultural transcendente, tanto ao homem, como à cidade.

\section{6 - CONCLUSÃO}

Embora haja um perfil sucinto do turista do segmento religioso no Brasil, revelado através de pesquisas, há a necessidade de um maior compromisso dos órgãos públicos e privados em desenvolver projetos de qualidade, que priorizem a qualidade de vida dos turistas brasileiros, que visitam outros Estados e Regiões, assim como, os turistas de outros países.

A fim de atribuir qualidade à prestação de serviços em conjunto com produtos formatados de acordo com as necessidades e desejos dos clientes, 0

\footnotetext{
${ }^{24}$ Deusdedith Junior, 2003, p. 139

${ }^{25}$ Beni, 1998, p. 84
} 
marketing com suas ferramentas e técnicas adaptáveis a cada tipo de situação, demonstra ser o meio mais adequado para se atingir os objetivos esperados em cada trabalho dentro do turismo.

Sabe-se que a expectativa do cliente, quanto aos atributos que considera mais relevantes, seja atendida, como: os atributos básicos, os atributos esperados e aqueles inesperados, dependendo do investimento e do tipo de produto que esteja comprando.

Desta forma, devem ser contemplados todos os projetos que se façam presentes no setor do turismo e no segmento que cada vez mais ganha a simpatia de pessoas em todo o Brasil, como o religioso.

O ponto de fé traçado à partir da leitura da cidade, vista como forma de organização social, permite conceituar os locais de práticas místico-religiosas, quanto ao valor coletivo das pessoas com o espaço físico.

Deste modo, chega-se às formas tangíveis e intangíveis que caracterizam o ponto de fé em relação aos turistas.

O turismo religioso pode motivar as pessoas a praticarem outras modalidades de turismo, dependendo da localidade onde esteja inserido. O ponto de fé, como proposta, pode também ser entendido pelo turista como um local de retorno para a prática do turismo, pela boa receptividade, pelos atrativos disponíveis e pelo rápido acesso, conforme as boas condições de infra-estrutura.

Não se pode pensar em segmentar esse tipo de turismo de massa em partes menores, fazendo uso das técnicas de marketing, de modo a controlar o fluxo de turistas que marcham em multidões como romarias e peregrinações, pois corre-se o risco de descaracterizar o evento religioso. As datas já fazem parte da vida dos fiéis, que religiosamente retornam nos próximos anos. Neste caso, deve- 
se usar o marketing para divulgação do evento, para os turistas que ainda não conhecem o local, na melhoria do trade turístico, fomentando novos projetos locais para maior comodidade dos turistas e que vise, sobretudo, a qualidade de vida da comunidade local.

\section{7 - BIBLIOGRAFIA}

ALVES, Rubem Azevedo. O que é religião. São Paulo: Brasiliense, 1984.

ANSARAH, Marília Gomes dos Reis. Turismo: Segmentação de Mercado. São Paulo: Futura, 1999.

BENI, Mário Carlos. Análise Estrutural do Turismo. São Paulo: SENAC, 1998.

BOCOCK, R \& THOMPSON, K. (org.) Religion and Ideology. Manchester: Manchester University Press/ The Open University, 1985

COBRA, Marcos. Marketing de Turismo. São Paulo: Cobra Editora \& Marketing, 2001.

DURKHEIM, Émile. As formas elementares da vida religiosa: o sistema totêmico na Austrália. São Paulo: Martins Fontes, 1996.

IKEDA, Ana Akemi. O Marketing em Empresas de Pequeno Porte e o Setor de Serviços: Um estudo em Agências de Viagens. Brasília: SEBRAE, 1995.

KOTLER, Phillip. Marketing. São Paulo: Ed. Atlas, 1996. 
ROCHA JUNIOR, Deusdedith Alves. "A Cidade é um texto: apontamento para ler a cidade. In: Revista Universitas/Face, Brasília, v. 1, n. 1, 2003.

RODRIGUES, Antônio Edmilson Martins. Cultura urbana e modernidade: um exercício interpretativo. In: - Cultura. Substantivo plural. São Paulo: Editora 34, 1996.

RABAHY, Wilson Abrahão. Caracterização do turismo: uma análise das motivações "Feiras e Congressos" e "Religiosa". Caderno de Estatísticas, São Paulo (SP). Disponível em $<$ http://www.sindetur.com.br/turismo_em_numeros/estatistica_13.pdf>. Acesso em 19 de março de 2004.

SIQUEIRA, Deis. As novas religiosidades no Ocidente: Brasília, cidade mística. Brasília: Unb, 2003.

. "Religiosidade e Turismo em Brasília". Apostila do Centro de Excelência em Turismo da Universidade de Brasília, abril, 2003

SOARES, Luiz Eduardo. O rigor da indisciplina. Rio de Janeiro: RelumeDumará, 1994.

TURNER, Victor Witter. Dramas, fields, and metaphors: Simbolic Action in Human Society. New York: Cornel University Press, 1975.

VAZ, Gil Nuno. Marketing Turístico: Receptivo e Emissivo. São Paulo: Pioneira, 2001. 
2. O CONCEITO DE MARKETING

6. CONCLUSÃO 


\section{1 - INTRODUÇÃO}

O presente trabalho tem por objetivo abordar o segmento de turismo religioso no Brasil, trabalhando o conceito de "Ponto de Fé".

O turismo religioso é considerado como turismo de massa, pois movimenta grande número de pessoas.

O turismo religioso, em sua essência, formado por um valor cultural marcante, substancialmente popular, admite a observação de que não distingue os turistas, entre si, por suas classes sociais. Apenas talvez, por seus locais de origem geográfica e de destinos turísticos, se estrangeiros ou cidadãos brasileiros, somente para a geração de dados e informações estatísticas.

A cidade, a sociedade heterogênea e devidamente organizada, o regime capitalista ocidental, as novas religiosidades, o misticismo, são tópicos a serem abordados de forma estratégica para o trabalho do conceito sobre Ponto de Fé, propondo ao mesmo tempo, uma continuidade nas discussões sobre o turismo religioso no Brasil.

Com base em pesquisas bibliográficas, experiências próprias e observações sobre o assunto em questão, a direção a ser tomada será a de diferenciar o Ponto de Fé dos demais atrativos religiosos, ressaltando os valores pessoais, os motivos que ocasionam os grandes deslocamentos que se caracterizam em turismo e, como conseqüência, devolvem aos atrativos, às regiões, Estados e aos países, além de divisas, empregos, melhor qualidade de vida para a população e, ainda criam para o país uma identidade turística consistente. 
A crescente procura por religiosidade, revela a busca por um bem-estar pessoal e, por vezes, como resposta aos conflitos sociais de naturezas diversas, que, em um contexto global, afetam direta e indiretamente o turismo.

Como forma de contribuição acadêmica, a abordagem sobre O Ponto de Fé Místico-Religioso como Atratividade Turística, sob a forma de pesquisa se faz, por maior discernimento e valorização dos atrativos religiosos em evidência no Brasil, dos demais atrativos criados, especificamente, para fins mercadológicos e exploratórios.

Sobre este aspecto, o marketing propõe o uso de ferramentas que, pelo seu uso estratégico, possibilitam a prestação adequada dos serviços prestados aos turistas em suas viagens. Os conceitos apresentados predefinem as ações que devem ser tomadas durante o planejamento dos serviços ofertados, a fim de satisfazer as necessidades e desejos dos turistas.

Sendo assim, o marketing focalizado no produto, promove uma associação conjunta entre os serviços (bem intangível) e o produto propriamente dito (bem tangível), como parte de um pacote, com a finalidade de satisfazer o turista.

Neste caso, o marketing, através de pesquisas de mercado, salienta o segmento de turismo místico-religioso, como um segmento promissor para as empresas especializadas em serviços turísticos com foco voltado ao atendimento desta clientela específica.

Assim, surge a necessidade de abordar aspectos sobre o ponto de fé e tudo o que envolve sua conceituação, do ponto de vista do turista, do profissional de marketing, do de turismo e dos demais setores envolvidos direta ou indiretamente 
com a área, bem como, algumas formas de movimento religioso que definem os turistas em suas ações e práticas religiosas.

Visto como turismo de massa, o turismo religioso pode ser entendido a partir da observação e da leitura sobre cidade, através de dados meramente quantitativos, considerando apenas os números e não a relação entre as pessoas, onde os lugares por vezes se confundem com as pessoas. Desta forma, apura-se a percepção da idéia sobre o ponto de fé consagrado historicamente, daqueles criados para fins específicos que se justificam através de trabalhos de intensa promoção.

\section{2 - O CONCEITO DE MARKETING}

Sobre os conceitos, pode-se dizer, que fornecem uma estrutura especulativa sobre a ação e o modo de se articular as idéias, as experiências, os resultados da pesquisa, favorecendo ainda se colocar as idéias na prática.

Diante das diversas definições de marketing apresentadas por autores e profissionais da área, destaca-se a de Philip Kotler enraizada na lógica da natureza e do comportamento humanos, segundo ele, "marketing é a atividade humana dirigida para a satisfação das necessidades e desejos, através dos processos de troca". ${ }^{1}$

Através do marketing, espera-se atingir as expectativas do cliente, dando maior abrangência aos processos que envolvem o produto ou serviço, tanto em sua criação como no acompanhamento dos mesmos junto ao cliente.

\footnotetext{
${ }^{1}$ Kotler, 1996, p. 31.
} 
Pode-se entender o conceito de marketing como sendo os esforços para realizar as trocas em potencial, objetivando atingir as necessidades e desejos humanos. Os mercados são portanto, o ponto de partida para os planos e estratégias de marketing.

Os especialistas em marketing devem preocupar-se com as necessidades básicas fundamentais à sobrevivência dos seres humanos, mesmo sabendo que seus produtos estejam mais voltados a atribuir habilidades e em satisfazer as necessidades de ordem elevada de seus consumidores. Por essa percepção, pode-se identificar melhor as possíveis necessidades que uma pessoa esteja procurando satisfazer com a aquisição de um produto e como se dá o processo de mudança dessas necessidades através do tempo.

Para o profissional de marketing, é importante que se avalie o grau de satisfação que seu produto irá proporcionar ao cliente, o desejo que o consumidor têm em realizar a compra de um determinado produto e o que ele almeja ou, o que ele espera atingir com esse produto. O consumidor interessa-se em saber como o mesmo situa-se em relação aos atributos que são mais importantes para ele.

Desta maneira, o marketing procura obter lucros através da satisfação dos clientes, contrapondo-se à idéia de venda única e exclusivamente.

Um bom trabalho de marketing explica o sucesso duradouro na conquista de novos mercados e na fidelidade de seus clientes, pois procura orientá-los para o consumo através do marketing integrado, direcionado para a satisfação do cliente, para só então satisfazer aos desejos da organização.

Do ponto de vista da atividade turística, que cada vez mais vem ganhando espaço no mercado nacional e internacional, Gil Nuno Vaz $^{2}$ utiliza como referência uma definição de marketing turístico de Philip Kotler, segundo a qual: "Marketing

\footnotetext{
${ }^{2}$ Gil Nuno Vaz, 2001, p. 18.
} 
turístico é um conjunto de atividades que facilitam a realização de trocas entre os diversos agentes que atuam, direta ou indiretamente, no mercado de produtos turísticos".

Esta visão ampla, identifica todo o universo que envolve o ambiente mercadológico de trocas e, além disso, apresenta uma noção maior do marketing para o turismo.

Os conceitos formulados por Kotler sobre marketing, são o resultado e a conclusão de um trabalho que deve ser feito anteriormente ao processo de criação de um produto, com o intuito de definir quais as necessidades, desejos e valores que o cliente atribui dentro de um dado mercado, para que a organização possa adaptá-las, a fim de promover as satisfações desejadas, opondo-se, desta forma, aos concorrentes.

Sobre esse aspecto pode-se entender que, a organização concebe suas missões em termos de satisfazer a um conjunto de desejos definidos de um grupo de clientes específicos ou seu mercado alvo e usa a segmentação de mercado para melhor atingir os objetivos da empresa com relação ao que está sendo oferecido e exposto no mercado (como produto) para uma clientela específica.

Com isso a empresa reconhece que a satisfação de desejos requer um ativo programa de pesquisa de marketing para conhecer esses desejos e, deste modo, estará cativando seus clientes levando-os a realizarem futuros negócios com a empresa. A organização reconhece também que todas as atividades de influenciar clientes devem ser colocadas sob um controle integrado de marketing e que deve ser feito um acompanhamento prévio do produto e seu uso, afim de minimizar possíveis problemas.

A empresa ao manter esse foco de satisfazer os clientes, ganha sua lealdade, repetição de negócios e palavras de recomendação. Aspectos que são 
cruciais na satisfação dos objetivos da organização e que devem ser tidas como pontos óbvios na atividade de marketing por parte dos empresários e das organizações.

Devido à amplitude do mercado em potencial, é preciso que se faça uma distinção entre o conceito de marketing e o conceito de venda, para que se possa distinguir as diferenças no trabalho para obtenção dos lucros entre esses dois setores.

Faz-se necessário, por parte de muitos empresários e do público, saber a diferença entre vendas e marketing, com o propósito de direcionar, da melhor forma possível, as necessidades do cliente diante de um produto, como também, informar sobre o melhor método a ser utilizado para a venda de seus produtos.

A venda está direcionada, a princípio, para as necessidades do vendedor. Busca efetuar o maior número de vendas possível, enquanto que o marketing está centrado em atingir as necessidades do comprador através do seu produto e nos diversos itens associados à criação, entrega e o consumo final.

Percebe-se que ambos os setores visam, ao final de seus trabalhos, o lucro, mas usando caminhos opostos. Enquanto a venda procura atingir seus lucros através de um volume crescente de produtos supostamente existentes, o marketing preocupa-se com todo o processo que envolve seu produto, tendo como principal enfoque o cliente, buscando satisfazer desde o valor físico até o valor emocional atribuído a este produto pelo cliente em potencial.

Quem deve dizer aquilo que deverá ser realmente produzido é o cliente. Ou seja, quem irá consumir o produto, quem irá pagar por ele. Então, a partir daí, poderão ser minimizados os gastos das empresas na reformulação dos produtos e estabelece-se, de maneira mais eficaz, a harmonia entre a empresa e seus clientes, através dos produtos e a forma como são trabalhados. 


\subsection{MARKETING DE PRODUTOS}

Para os setores que não visam lucro, o marketing, também, vem crescendo a cada dia. Os clientes têm atualmente muitas opções na hora de decidir por quais serviços e produtos deva escolher. É o caso de faculdades, hospitais, igrejas ou até mesmo de grupos teatrais e artísticos, dentre outros.

Alguns destes setores procuram utilizar-se das técnicas empregadas pelo marketing somente para campanhas ou temporadas com prazos definidos ou por regiões de atuação como é o caso dos grupos de teatro ou artistas. Já outros setores organizacionais como faculdades, hospitais e igrejas, em alguns casos, reconhecem a necessidade de se ter um profissional da área de marketing para direcionar os caminhos a serem tomados pela organização frente aos seus clientes.

O marketing, através da satisfação do cliente com seu produto, torna a venda um ponto secundário a ser atingido, mas não esconde a necessidade de se fazer uma pesquisa de mercado minuciosa, para que seu trabalho final seja consistente e atinja seus objetivos. O cliente sempre será seu foco principal, então torna-se obrigatório conhecer, avaliar e estudar o comportamento do seu cliente a fim de estabelecer um diferencial com relação aos concorrentes.

A percepção das empresas em direcionar seus produtos às necessidades $\mathrm{e}$ desejos dos clientes deu-se de forma gradativa, quando viram que a grande produção de bens de consumo não atingia por completo a satisfação de seus clientes, ocasionando, conseqüentemente, queda nas vendas.

As empresas constataram que os clientes só consumiam aqueles produtos que realmente fossem úteis e adequados a cada ocasião. Então começaram a orientar-se através de pesquisas de mercado, observando mais de perto seus 
clientes, suas necessidades e desejos, como portavam-se os concorrentes diante do mercado em potencial e aquilo que estava sendo ofertado de acordo com a preferência dos clientes.

Sobre este aspecto, Kotler $^{3}$ afirma que o trabalho de marketing deve ser empregado para que se obtenha sucesso e aponta o marketing como sendo o processo pelo qual uma organização desenvolve e ajusta sua oferta às mudanças constantes das necessidades e desejos do mercado.

Por parte das empresas, observou-se então que era preciso ajustar, gradualmente a oferta de seus produtos, buscando adequá-los, precisamente, às necessidades e desejos de cada mercado, observando as mudanças constantes e a dinâmica de cada um com relação ao tempo.

A atenção das empresas, neste momento, voltou-se, de um contexto mais abrangente de mercado, para um mercado específico. Tinha-se anteriormente uma idéia de atingir um número maior de clientes frente a um produto ou serviço, sem considerar a satisfação plena dos clientes. Isso dificultava consideravelmente o estabelecimento da empresa no mercado, pois ocorriam constantes quedas nas vendas, uma vez que os produtos eram fabricados sem levar em consideração as necessidades e desejos dos clientes.

A segmentação desse mercado foi uma saída estratégica e de fundamental importância para as organizações. A partir de então, a empresa pôde identificar o mercado específico de clientes garantindo à ela uma identidade frente ao mercado que atuava.

À partir daí, o próximo passo a ser dado pelas empresas foi o de identificar a maneira como deveriam ser trabalhados os produtos e serviços no mercado em potencial.

\footnotetext{
${ }^{3}$ Kotler, 1996, p.35.
} 
Se acreditassem que o consumidor favoreceria os produtos mais disponíveis e de menor preço do mercado, a produção então teria que estar centrada em larga escala e distribuição. Esta visão de atuação encontra condições propícias de desenvolvimento nos mercados em que a demanda é maior do que a oferta e para as empresas nas quais os custos são elevados, podendo ser reduzidos através de um aumento na produção.

Se fosse identificada a necessidade de se trabalhar o produto, teriam então que chamar a atenção dos consumidores apresentando maior qualidade e inovações dos produtos dentro do mercado. Estariam assumindo em correr o risco de se não acompanharem as mudanças de desejos dos mercados, poderiam decretar a falência da empresa.

Com o enfoque de trabalho para as vendas, as empresas estariam direcionadas para a crença de que o cliente estará sempre consumindo o que as organizações produzem e não aquilo que o mercado deseja consumir no momento. Pensa-se em criar, nesta visão, uma necessidade no cliente de que ele, por conta própria, não irá comprar o bastante.

Se a empresa chegasse a conclusão de que seu foco de trabalho deveria ser voltado para o marketing, o interesse da organização estaria em determinar as necessidades e desejos do mercado, a fim de satisfazê-los de modo mais sublime que os concorrentes, tendo o lucro como uma conseqüência dos esforços dessa atividade. Mas antes, conhecer o mercado através de pesquisas com os clientes e analisando a forma de atuação da concorrência, seus pontos fortes e seus pontos fracos.

Porém, dando enfoque no marketing social, as organizações podem determinar, além das necessidades e desejos e interesses do mercado, 
satisfazendo-os mais eficientemente, fixar na consciência dos clientes, que tanto a empresa quanto seus consumidores possuem os mesmos pontos de vista, valores e atitudes, dentro do contexto sócio-ambiental em que estão inseridos.

Os consumidores sabem distinguir o comportamento de cada empresa no mercado, logo, eles as aprovam ou reprovam dependendo do comportamento de cada empresa em seu papel social. Neste enfoque, deve-se saber que o cliente não está preocupado somente em atender suas necessidades e desejos, mas em fazer com que as necessidades gerais do ambiente em que se encontra sejam consideradas e atendidas pelas empresas.

\section{2 - MARKETING DE SERVIÇOS}

São muitas as definições de serviço, pois são diversos os setores econômicos que podem ser empregados. A cada definição pode ser considerado um ponto de vista dos trabalhos desenvolvidos em cada segmento empresarial, juntamente com a percepção do consumidor.

A definição de Stanton ${ }^{4}$ abrange melhor os trabalhos realizados em turismo:

Serviços são atividades intangíveis, separadamente identificáveis que fornecem satisfações desejadas quando colocados aos consumidores e/ou usuários industriais e que não são necessariamente ligados a venda de um produto ou outro serviço.

As características dos serviços foram, durante algum tempo, muito questionadas, pois não se tinha uma visão genérica dos benefícios proporcionados, tanto para os clientes, como para os empresários e fornecedores, em sua área de atuação. 
Sabe-se, pois, que os serviços possuem características próprias diante do consumidor.

Intangibilidade - os serviços não passam por nenhum dos sentidos do consumidor antes de serem adquiridos. Para comprá-los, o consumidor precisa depositar certo grau de confiança no fornecedor, que por sua vez, para dispor o serviço, deve não somente fazer uma descrição das características do serviço, mas dar ênfase aos benefícios do produto. Ou ainda, dar nomes de marcas aos serviços ou trabalhar a imagem de pessoas públicas, vinculando-as aos serviços, para credibilizar os serviços e aumentar a confiança do consumidor. Por este trabalho, o fornecedor procura tornar tangível os serviços.

Inseparabilidade - assegura que um serviço está obrigatoriamente ligado a seus fornecedores, sendo pessoas ou máquinas. Para o caso de pessoas, o fornecimento dos serviços com relação ao tempo, pode ser caracterizado ou moldado para cada cliente, no esclarecimento de dúvidas, queixas, pedidos, etc. No caso de máquinas, há uma padronização de tempo e de qualidade no fornecimento de um serviço, desconsiderando o diálogo e um atendimento personalizado. Neste último, subentende-se que o cliente já tenha um conhecimento prévio deste tipo de fornecimento de serviço.

Variabilidade - depende de cada fornecedor, do local onde será fornecido e também do período em que se encontrará disponível o serviço. Os consumidores reconhecem esta dinâmica da variabilidade dos serviços e geralmente procuram informações a respeito com outras pessoas antes de formalizarem a escolha de um prestador. Neste momento, o fornecedor deve procurar garantir qualidade nos serviços, com funcionários selecionados e treinados para um contato direto com o cliente, trabalhando a satisfação do consumidor através de um acompanhamento,

\footnotetext{
${ }^{4}$ Stanton, 1974, p. 545, apud Ana Akemi Ikeda, 1995, p. 91
} 
coletando sugestões, anotando críticas e reclamações, para identificar e corrigir erros.

Perecibilidade - os serviços não podem ser estocados ou armazenados como alguns produtos. Para que um serviço seja disponibilizado, há um gasto anterior que procura reverter o capital empregado e obter uma certa margem de lucro. O serviço não sendo consumido, declara o prejuízo de investimento, que jamais poderá ser recoberto.

Em turismo, os serviços complementam-se naturalmente, entre aspectos tangíveis e intangíveis, podendo ser comprados e consumidos ao mesmo tempo pelos clientes. A tangibilidade desses serviços é caracterizada por atributos físicos e a intangibilidade, por benefícios ofertados ao cliente e satisfações proporcionadas pelos serviços. Embora esta distinção seja feita, há momentos em que um produto é confundido com um serviço, como em um restaurante. Em uma refeição, encontram-se os produtos alimentícios, de caráter físico, ou seja, produto tangível, preparada e servida por um serviço, de caráter imaterial, produto intangível. Grande parte dos produtos turísticos, para serem consumidos, precisam ser assistidos, desde a preparação, até o fim de seu consumo, por um serviço.

Os componentes de um serviço turístico podem ser classificados em quatro níveis dos atributos mais considerados pelos clientes e pela concorrência, são eles: básicos, esperados, desejados e inesperados.

Os atributos básicos são aqueles mínimos que um cliente pode encontrar, entre aspectos tangíveis e intangíveis, para se realizar um negócio. As empresas que apresentam somente atributos básicos a seus clientes são consideradas ruins caso os concorrentes estejam oferecendo outros de nível mais elevado. 
Os atributos esperados são aqueles que o cliente já considera fazer parte do negócio. Para eles, a empresa que oferece apenas atributos básicos e esperados, é considerada satisfatória.

Os atributos desejados são os que o cliente apreciaria se fossem ofertados e inclusos no negócio, embora não os espere. A empresa passa a ser beneficiada pela procura dos clientes se realmente estiver realizando melhor trabalho que os concorrentes.

Os atributos inesperados são aqueles que surpreendem e adicionam valor para o cliente, indo além do que o consumidor espera. Àqueles que fazem um bom trabalho em surpreender o cliente, têm a preferência. $O$ cliente indica a empresa, ou fornecedor, para outros, através da propaganda boca a boca. É importante que a organização saiba que, após algum tempo, estes atributos se tornarão esperados pelo cliente. A empresa deve então investir em pesquisas a procura de novos atributos inesperados, para que continue a surpreender 0 cliente. Desta forma também estará limitando a atuação da concorrência.

A importância de uma pesquisa bem elaborada no setor de serviços é a garantia da boa imagem da marca de uma empresa, da plena satisfação dos clientes e o orgulho dos funcionários, sendo também, um pesadelo para os concorrentes despreparados.

Mas os trabalhos de coleta de dados e informações a respeito da atuação da concorrência no mercado, por parte das empresas fornecedoras de serviços, são recentes. Há também, a ausência de dados específicos, o que dificulta o trabalho de marketing no acompanhamento e gerenciamento dos serviços ao cliente. 
Para que tais atividades desenvolvam-se em perfeita sintonia, faz-se necessário que as unidades produtivas de bens e serviços turísticos adeqüem-se aos fatores de produção, para otimizar o volume da oferta.

A adequação das unidades produtivas de bens e serviços turísticos aos fatores de produção, explica-se da seguinte forma: Os fatores de produção, em conjunto, formam a unidade do produto turístico, que necessita basicamente dos serviços para chegarem ao cliente. No mercado são expressos na forma de bens e serviços, que serão consumidos de acordo com as variáveis da demanda.

Os principais atores desta dinâmica atividade mercadológica de desenvolvimento do turismo, seja em um país, uma região ou município, são as organizações públicas e privadas, que controlam tanto a venda como a produção de bens e serviços.

A importância do Bacharel em Turismo e sua proposta de trabalho é justamente fazer com que haja uma interação, um trabalho em conjunto entre a organização pública e privada, de maneira que todos possam usufruir dos benefícios que o turismo oferece, tendo como foco de ação o trabalho de marketing.

No turismo, os serviços estão em uma escala proporcional maior que os produtos ofertados à demanda. Pode-se imaginar que para cada produto produzido ou ofertado por uma empresa aos clientes são agregados inúmeros serviços, até o consumo final de cada produto.

A importância dos serviços agregados aos produtos pode ser entendida como o trabalho de um joalheiro em um diamante bruto encontrado na natureza. Ele lapida, modela e dá forma ao diamante, atribuindo beleza e valor, de modo a causar impacto aos olhos do cliente. Sem o serviço, fica difícil que um produto em si, atinja a eficácia em atender plenamente as necessidades e desejos do cliente. 


\section{3 - RELIGIÃO E MISTICISMO}

Tendo o turismo religioso como base para o início de estudos acadêmicos, aos poucos, pode-se observar que, sua importância, está intimamente ligada à vida particular das pessoas que viajam pelo mundo a lugares místico-religiosos, a procura de descanso e conforto espiritual.

E, como se a busca pelo sagrado, o celestial e grandioso ser criador de todas as coisas levasse a todos a adotar uma postura de religiosidade como condição vital, misticismo e religião então separam-se por modo de definição.

Embora se possa entender intuitivamente o que venha a ser definido como religião, Rubem Alves explica antes que, a religião aparece como uma "teia de símbolos, rede de desejos, confissão da espera, horizonte dos horizontes, a mais fantástica e pretenciosa tentativa de transubstanciar a natureza" ${ }^{\text {". }}$.

De acordo com essa definição, pode-se entender que as pessoas procuram criar uma linguagem para aquilo que elas não podem ver, mas somente ser sentido sob a forma emocional. Em nada pertencendo a fatos e caracteres excepcionais.

Para Rubem Alves: "A religião nasce com o poder que os homens têm de dar nomes às coisas, fazendo uma discriminação entre coisas de importância secundária e coisas nas quais seu destino, sua vida e sua morte se dependuram"

\footnotetext{
${ }^{5}$ Alves, 1984 p. 22

${ }^{6}$ idem, p. 24
} 
Assim, nessa abordagem, os objetos recebem nomes e usos conforme cada tipo e são também classificados como prioritários, dependendo do grau de importância e da diferença que possam fazer para a sobrevivência do homem. Desse modo, quando o homem se reporta a algum personagem de sua religiosidade, ele a produz, de alguma forma, em seu imaginário.

Embora seja entendido, que a religião não parta somente do imaginário popular, ela sugere valores sentimentais de amor, integridade e poder pela fé, que por vezes, são distorcidos pela ciência. É o que destaca Rubem Alves, por um comentário de Durkheim: "Diz-se que a ciência, em princípio, nega a religião. Mas a religião existe. Constitui-se num sistema de fatos dados. Em uma palavra: ela é uma realidade. Como poderia a ciência negar tal realidade?"7.

Esse reforço afirmativo sobre a existência da religião, embora a ciência diga e tente comprovar o oposto, permite admitir que, a religião exerce um papel importante na sociedade, observando-se o segmento de turismo religioso e, para a própria ciência que a toma como ponto de partida para suas pesquisas, tentando dar respostas às perguntas como: De onde viemos? Qual a verdadeira origem da vida? Por que somos desta ou daquela forma? E etc.

A visão de mundo sob os aspectos materiais e imateriais dá às pessoas, motivos e condições para a sobrevivência da vida social. É esse o propósito de investigação de Durkheim sobre investigação da religião.

Já sobre o misticismo, observa-se que há uma real atitude por parte dos místicos uns com os outros e com o próximo, sob uma busca comum em relação ao sagrado. 
Segundo Deis Siqueira: "misticismo é definido como a atitude humana que visa à união das pessoas com as forças sagradas, transcendentais, o mistério fascinante". 8

Esse conceito revela a busca do homem pelo ser divino que se materializa nos animais, nas pessoas, nos elementos e fenômenos da natureza, nos fatos e acontecimentos inexplicáveis, que acompanham o homem desde sua origem mais primitiva.

Atualmente, o que se vê é uma exposição maior do misticismo, e de identificação pessoal de novos adeptos, que buscam novas experiências espirituais. Talvez, essas dados sejam mais comuns aos habitantes de BrasíliaDF, que é considerada uma cidade mística por natureza e história e, ainda mais, para as pessoas que moram na cidade de Alto Paraíso de Goiás, localizado a aproximadamente $230 \mathrm{Km}$ de Brasília, marcado pelo grande número de adeptos místico-esotéricos, tida como paraíso e que recebe, constantemente, a visita de turistas pertencentes a esse segmento.

Em Brasília cidade planejada para ser a sede do Governo Federal e centro das decisões políticas do país, Segundo Deis Siqueira, "religiões tradicionais, tais como o budismo e outras religiões centradas nas Escrituras Védicas, estão sendo revividas no Ocidente e particularmente em Brasília, dentro da perspectiva de uma nova religiosidade e de um novo estilo de vida, que se diferenciem das religiões ocidentais tradicionais cristãs"9.

Brasília surge então, sob esse ponto de vista, como uma cidade moldada pelos aspectos místico-religiosos e de grande potencial turístico a ser explorado.

\footnotetext{
${ }^{7}$ Durkheim, apud idibem, p. 58

${ }^{8}$ Siqueira, 2003 p. 16.
} 
Assim, em terreno fértil, surgem outros "movimentos religiosos" ou extensões religiosas advindas das religiões tradicionais, a citar: o Cristianismo, o Judaísmo, o Budismo, o Islamismo, Confucionismo, Taoísmo, Xintoísmo e o Bramanismo (Hinduísmo).

Há também que se ressaltar que as pessoas que se dizem não pertencentes a nenhuma das religiões tradicionalmente conhecidas, mas que em algum momento de suas vidas participaram de algumas delas, em sua grande maioria são definidas por Deis Siqueira como pessoas que atualmente estão:

"construindo sua religião numa espécie de bricolage, compondo, por conta própria, doutrinas, práticas, rituais, que vão sendo incorporados a partir de vivências ou experiências em vários desses grupos místicoesotéricos e com as práticas não convencionais ou alternativas de cura, de auto conhecimento, em boa medida associados aos valores e visões de mundo desses grupos" ${ }^{\prime 10}$.

Vale destacar os movimentos das massas que se dirigem aos templos supremos da fé ou a algum ponto de devoção de crenças, como os templos secundários, igrejas, sinagogas, mesquitas, etc.

O Cristianismo é a religião mais abrangente do mundo, contando mais de 1,7 bilhão de adeptos distribuídos por todo o planeta ${ }^{11}$. No Brasil é a religião predominante, de acordo com o último censo, e os fiéis, sempre à procura do perdão, acabam por realizar diversas festas de Santos Católicos para poderem pagar suas penitências.

\footnotetext{
${ }^{9}$ Idem, p. 40

${ }^{10}$ idbidem, p. 40

${ }^{11}$ ONU, http://www.onu.org, acesso em 12 de Janeiro de 2004.
} 
O Islamismo, importante religião mundial (a população muçulmana é estimada em mais de 935 milhões $^{12}$, originária da península da Arábia e baseada nos ensinamentos de Maomé (570-632), chamado o Profeta. Esta religião, segundo os dados da ONU, é a que mais cresce no mundo. Devido a uma prática obrigatória para todos os fiéis da religião, pode-se observar um dos maiores movimentos de peregrinação do mundo, pois todo fiel deve, pelo menos uma vez na vida, visitar a cidade de Meca, na Arábia Saudita.

Há também, os chamados novos movimentos religiosos, sobre eles, destaca-se o movimento New Age, definido por Deis Siqueira, "como um conglomerado de tendências que não teria textos sagrados ou líderes, nem organização fechada ou estrita nem dogmas". ${ }^{13}$ De certa forma, são tidos como movimentos não litúrgicos pela ausência de escrituras sacramentais ou qualquer espécie de liderança organizada e predefinida.

Ainda sobre as diversificadas atividades do movimento New Age que atrai mais e mais adeptos a essa visão de mundo, Deis Siqueira agrupa as técnicas que compreendem esses grupos pelas práticas de "curandeirismo, geomancia, cartomancia e astrologia pertencem ao repertório tradicional de cura e conselhos práticos das sociedades pré-industriais" ${ }^{* 14}$, retomando, atualmente, sua popularidade.

Entendidas como um novo estilo de vida, as novas religiosidades por grupos místico-religiosos, remontam uma forma de evolução pessoal, através das realizações pessoais sobre a divinização, pela continuidade das experiências vivenciadas, que ajudam a definir caminhos próprios e visões de mundo material e

\footnotetext{
${ }^{12}$ ONU, http://www.onu.org, acesso em 12 de Janeiro de 2004.

13 op. cit. Siqueira, p. 19.

${ }^{14}$ Idibem, p. 34
} 
imaterial, entendidas pela interpretação dos estudos de Deis Siqueira sobre a psicologização das religiões ${ }^{15}$.

Como mostrado anteriormente, sobre a importância de se abordar aspectos desse segmento, composto por um público extremamente significativo, vale lembrar que, à medida em que são descobertos novos nichos de mercado, que por sua vez é composto de pessoas, novas exigências de clientela são percebidas pelos produtos e serviços dispostos para consumo. No caso específico do turismo, isso significa que todo o trade turístico como: bares, restaurantes, hotéis e pousadas, agências e operadoras de viagem, companhias aéreas, dentre outros atores envolvidos, devem redirecionar seus esforços organizacionais para atender a essa nova demanda. O motivo é simples, garantir a sobrevivência das empresas num mercado altamente competitivo.

A religião, de certa forma, está presente na vida das pessoas há séculos, através de liturgias e dogmas, funcionando como um norteador, embora, com o passar dos tempos, venha sofrendo mudanças singelas para acompanhar as novas inclinações da sociedade na expressão de suas crenças.

Por essa razão, tornam-se cada vez mais freqüentes o desenvolvimento de projetos voltados a esse tipo de segmento dentro do turismo. O chamado turismo místico-religioso tem mantido fluxo constante de turistas pelas diversas localidades regiões do Brasil.

Pelo tipo de religiosidade praticada no Brasil, movimento de massas, podese constatar que o conceito que mais se aproxima, é o de Durkheim ${ }^{16}$ :

\footnotetext{
15 ibidem, p. 93

${ }^{16}$ Durkheim, apud, Bocock e Thompson, 1985, p. 42
} 
A religião é algo eminentemente social. As representações religiosas são representações coletivas que expressam realidades coletivas; os ritos são de uma maneira de agir que ocorre quando os grupos se reúnem, sendo destinados a estimular, manter ou recriar certos estados mentais nesses grupos.

O grande motivo de se entender a religião e os cultos místicos em prática nos dias de hoje, ocorre para facilitar o entendimento de que a sociedade caminha conforme seus valores de coletividade, como se possuísse uma identidade própria, e ela possui. Seus órgãos e instituições podem ser vistos como membros de um corpo humano em toda sua complexidade.

E quando se fala em religião ou misticismo ou qualquer outra forma de crença, estabelecem-se, logo em seguida, os valores pessoais, as formas de cultura existentes conquistas materiais. Sendo esta última, a mais próxima e passível de realização, ou não, que leva o homem a buscar complemento ou razão para sua existência. Busca-se alcançar o intangível, resgatar seus antigos valores, deixados de lado pela filosofia do materialismo, então, mudam-se os hábitos e a maneira de pensar sobre os fatos da vida cotidiana, de modo que a vida passe a fazer sentido.

Assim, a religião floresce no homem de acordo com o poder de imaginação que cria sobre as coisas. O mundo material é e sempre será como a construção do imaginário dos homens, o poder de idealização de seus sonhos. A religião funciona como uma busca pelo aperfeiçoamento da alma e uma relação mais possível com o próximo. 


\section{4 - O PONTO DE FÉ}

O Ponto de Fé ou Ponto de Atração de Fé é um ponto turístico criado a partir do imaginário popular ou de uma relação religiosa institucionalizada, que motiva as pessoas a buscá-lo através do turismo.

O turismo sempre se fez valer pelas atratividades naturais ou construídas, e até mesmo transformadas pelo homem. No caso, O Ponto de Fé é uma nova modalidade de atrativo, onde as pessoas não irão por motivo de diversão ou de lazer e sim, para uma busca espiritual, independente de suas crenças religiosas.

As religiões de massa sempre proporcionaram "espetáculos" de movimento em busca desses pontos. Alguns desses pontos de fé, confundem-se com pontos criados pelo homem, mas a relação entre o homem, que busca o ponto e Deus (Ser Supremo), não está inserido neste tipo de construção, e sim, em uma relação transcendental.

As pessoas, em muitos casos, não criam o Ponto de Fé intencionalmente, pois o mesmo é fruto de uma massificação do lugar, não estando reservado a uma cidade ou a uma igreja específica, como exemplos. Pois o Ponto de Fé, pode ser intangível, como um local de aparições, como Medjugore, ex-lugoslavia ou um caminho, como o de Santiago de Compostela. Para muitas religiões existem manifestações que são explicadas apenas por meio da fé, sem o auxílio da ciência, dando o caráter de intangibilidade do ponto. 


\subsection{FORMAS DE MOVIMENTO RELIGIOSO}

No Brasil, o movimento religioso católico define o turismo religioso em três formas e objetivos, distinguidos pelos fiéis, que são: as romarias, as peregrinações e as penitências.

As romarias são feitas somente com o intuito de viajar a lugares sagrados, por vontade própria e em muitos casos, sem objetivar recompensas materiais ou espirituais. Os romeiros comumente perfazem todo o roteiro turístico da localidade que esteja em algum momento ligado à fé e devoção, como obras de arte sacra e altares de igrejas de séculos passados ${ }^{17}$.

As peregrinações podem ser entendidas quando as pessoas vão visitar lugares sagrados para cumprir promessas em devoção a algum santo e por ter alcançado ou para alcançar alguma graça. Pode-se identificar mais facilmente um peregrino, através de seus hábitos dirigidos a seu santo de devoção. Os pedidos para alcançar uma graça, geralmente são feitos quando o cristão visita um local de retiro espiritual pela primeira vez, sentindo que a passagem por aquele local tenha um significado religioso, como um chamado de Deus ${ }^{18}$.

As penitências são as expressões mais grandiosas de humildade por parte dos fiéis em admiração a um santo. Busca-se, através das penitências, a redenção dos pecados e culpas cometidas. As penitências são, na maioria das vezes, aconselhadas por líderes religiosos, mas podem também partir dos próprios fiéis, que as dirigem a locais sagrados em sentido de arrependimento.

A cada ano, vem crescendo o número de turistas que, por motivos religiosos, visitam cidades, estados e até vão a outros países como em Portugal, na cidade de Fátima. Através da religião exprime-se também a cultura de um

\footnotetext{
${ }^{17}$ Siqueira, Religosidade e Turismo em Brasília, 2003, p. 02
} 
povo, atuando como um agente social, garantindo proteção. A religião ajuda a resgatar antigos valores e a coibir atos anti-sociais que possam comprometer 0 futuro dos indivíduos.

Embora os dados mais recentes divulgados pelo Censo 2000 do IBGE (Instituto Brasileiro de Geografia e Estatística) demonstrem mudanças no perfil religioso do País, o turismo religioso tem crescido vertiginosamente. Pesquisas sobre os impactos econômicos do turismo religioso no Brasil, ainda que pouco expressivas e insuficientes, revelam que esse segmento revigora a economia local sob a ação das adaptações de equipamentos de hospedagens, terceirização de serviços, comércio e restaurantes, entretenimento, etc., salientando a sua importância para a região. Pode-se inferir então que, independentemente de qualquer religião, a procura por ajudas espirituais tem sido notável e constatada pela prática do turismo religioso.

"Segundo o IBGE, 11 milhões se converteram à religião evangélica nos últimos dez anos. É um aumento de 70\%. A umbanda e o candomblé estão desaparecendo, com apenas $0,3 \%$ dos brasileiros. A igreja católica sofreu uma queda recorde, perdeu 10\% dos fiéis, agora são 73,8\%. A menor proporção de católicos está no Rio de Janeiro, são pouco mais de oito milhões de pessoas. Os evangélicos estão aumentando, já representam $20 \%$ da população do estado do Rio, com três milhões de fiéis. No estado, há 400 mil espíritas e 200 mil seguidores de umbanda e do candomblé. Mas o Rio de Janeiro também tem o maior número de brasileiros que se dizem "sem religião". São 2,2 milhões de pessoas. São tantos os "sem religião" que ficaram em terceira posição, depois de católicos e evangélicos, 12.330 milhões de brasileiros". ${ }^{19}$

As mudanças no perfil religioso do Brasil foram diagnosticadas, ainda que muitos fiéis não concordem com os resultados divulgados pelo Censo 2000 do IBGE.

\footnotetext{
${ }^{18}$ Idibem, p. 02
} 
Em virtude da enorme evasão de fiéis, a igreja católica toma uma nova postura, criando os movimentos carismáticos, os movimentos pastorais, investindo mais em festas de santos padroeiros, com o surgimento de padres cantores, no lançamento de campanhas, serestas para casais, dentre outros eventos, fazendo com que os católicos tornem-se mais fervorosos e mais participantes na igreja.

Os números apontados pelo Censo 2000 do IBGE revelam que há, em todas as religiões, os chamados "fiéis modistas", que acompanham por partes e por um determinado período os tempos litúrgicos de cada religião.

\section{2 - PONTO DE FÉ TANGíVEL}

No caso específico do Brasil, observa-se um maior número de pontos de fé de caráter tangível. Sendo eles, em sua maioria, cidades que se apresentam como ponto de fé pela sua arquitetura, no caso, as igrejas, por festas de padroeiros ou pelas confluências de energias, no caso dos místicos.

As cidades que se destacam por suas igrejas, também remontam um caráter histórico, bastante influenciado por estilos de época, mas não perdem sua identidade com a fé, atraindo romeiros, peregrinos e fiéis, sendo estes os verdadeiros turistas de fé. Dentre elas destacamos: Aparecida, em São Paulo,

Ouro Preto e Congonhas, em Minas Gerais, Bom Jesus da Lapa, na Bahia, etc. Não se deve esquecer as outras formas religiosas com suas arquiteturas próprias. Exemplificando: as seitas de Alto Paraíso de Goiás, como a do Raio Violeta de Saint German e em Pirenópolis, também no estado de Goiás, com a Bolha.

Existem também, as cidades que atraem os turistas por conta de suas festas religiosas. Muitas festas referem-se aos dias reservados dentro do

\footnotetext{
${ }^{19}$ IBGE, Censo 2000, apud http://www.ibge.gov.br/censo, acesso em 12 de Janeiro de 2004.
} 
calendário aos santos e também, referente a algum tipo de milagre ou aparição. Essas cidades são, de certa forma, as mais visadas por conta de uma manifestação mais fervorosa por parte dos fiéis em relação ao santo de devoção. Pode-se citar O Círio de Nazaré, em Belém do Pará, dia 12 de outubro, Dia de Nossa Senhora de Aparecida e novamente, a cidade de Aparecida, em São Paulo. As outras formas religiosas possuem festas pouco divulgadas, que não merecem ressalva.

Existem outras cidades que possuem pontos atípicos. Cachoeira Paulista, em São Paulo, com o movimento Canção Nova, que atrai jovens e adultos de todo país, sem uma data específica, sendo o Carnaval, a Semana Santa e o acampamento dos músicos, em outubro, seus maiores fluxos. Juazeiro do Norte, no Ceará, muito conhecido por causa do Padre Cícero que, por seu envolvimento com a política, morreu excomungado pela igreja católica, não impedindo uma devoção por parte do sertanejo nordestino em torno de sua figura, proporcionando verdadeiro espetáculo de romarias, que fez com que a igreja revisse seu processo de excomunhão. E Guaratinguetá, em São Paulo, por conta das pílulas milagrosas do beato Frei Galvão, tais pílulas e a cidade, ficaram conhecidas após a beatificação do Frei Galvão.

Em outros países, assim como em outras religiões, pode-se observar outros pontos de fé e outras manifestações, trabalhando apenas as religiões de massa, que são as de maior número de adeptos, o cristianismo e o islamismo.

$\mathrm{Na}$ região de Jerusalém estão presentes templos religiosos de três religiões: judaísmo, cristianismo e islamismo. Para o cristianismo, a importância do ponto, se refere ao local de nascimento e morte de Jesus Cristo, sendo um excelente atrativo de fé para todos os cristãos do mundo. Logo, para as outras religiões, a região se designa apenas por possuírem templos religiosos, tais como: a Mesquita do Domo da Rocha, para os islâmicos, que acreditam que a mesquita fica sobre a rocha onde Maome pisou pela última vez antes de subir ao paraíso e 
o Muro das Lamentações, para os judeus, a última parte restante do templo construído por Salomão.

Roma, mais precisamente, o Vaticano, pode ser considerado o ponto de fé máximo da religião católica, por ser a residência e a sede da Igreja Católica Apostólica Romana.

A cidade de Meca, na Arábia Saudita é um ponto obrigatório para todo seguidor do islamismo. Pelo menos uma vez na vida, o fiel deve conhecer a cidade e tocar a pedra da Caaba, onde se encontram os restos mortais do profeta Maomé. Todo ano ocorrem peregrinações onde boa parte do mundo muçulmano se manifesta através de uma caminhada em direção a cidade, que por muitas vezes acaba em morte, causada por diversos fatores, entre eles, fome, doenças e pisoteio.

\section{3 - PONTO DE FÉ INTANGÍVEL}

A característica de intangibilidade do Ponto de Fé está relacionada com valor imaterial e intuitivo empregado pelas pessoas sobre as entidades divinas e das sensações de proximidade do ser cultuado, além de práticas místicas que proporcionam sensações agradáveis entre os componentes de um mesmo grupo.

Quando a visita a um determinado Ponto de Fé se faz pelo fato de se cumprir uma promessa por uma graça alcançada no mundo material, a intangibilidade ocorre pelo sentimento de uma missão que se cumpre, como tentativa de estabelecer um contato entre os dois pólos, o material e o imaterial.

Santiago de Compostela, na Espanha, é um exemplo, onde a visita à cidade só é consagrada, por meio de uma peregrinação, ficando conhecida como Caminho de Santiago. Esta peregrinação é o verdadeiro ponto de fé, pois a 
peregrinação começa na cidade de St. Jean Piet-de-Port, no sul da França, e após 750 quilômetros, em cerca de 30 dias, os peregrinos chegam à cidade. É importante ressaltar que existem outros caminhos para se chegar à cidade. Este é um exemplo de ponto de fé intangível, pois não se refere à cidade, mas sim ao ato de se percorrer o caminho até a cidade.

A cidade de Belém, no estado do Pará, também atrai turistas desse seguimento por conta da Festa do Círio de Nazaré, que se enquadra perfeitamente neste exemplo de intangibilidade.

Não se trata aqui, de mencionar pontos de turismo religioso, mas chamar a atenção pela força da fé do turista que escolhe determinado destino. Levando em conta apenas a sua fé ou sua tentativa de buscá-la.

\section{5 - TURISMO RELIGIOSO NO BRASIL}

Dentre os segmentos turísticos específicos como: turismo de eventos, de saúde, gastronômico, histórico, de lazer, dentre outros, o que mais tem chamado atenção, devido ao grande número de pessoas que movimenta, é o turismo religioso.

Tabela I - Propensão a viajar e a propensão por motivos Religiosos do total das viagens feitas. ${ }^{20}$

\begin{tabular}{|l|l|l|}
\hline \multicolumn{1}{|c|}{ Classe } & \multicolumn{1}{|c|}{ Propensão a viajar } & \multicolumn{1}{c|}{$\begin{array}{c}\text { Propensão a viajar por } \\
\text { motivos Religiosos }\end{array}$} \\
\hline 0 a 4 SM & 24,0 & 3,2 \\
\hline 4 a 15 SM & 38,3 & 1,4 \\
\hline Mais de 15 SM & 54,8 & 0,6 \\
\hline Total & 24,0 & 2,2 \\
\hline
\end{tabular}

*População Expandida; na População amostrada a propensão é de 36,4\%.

FIPE 
De acordo com os dados da pesquisa FIPE, 24\% da população brasileira realiza pelo menos uma viagem doméstica a cada ano, sendo o motivo "Religião" representado por 2,2\% desse total. De acordo com a tabela I acima, pode-se observar que há uma motivação maior por parte dos turistas de baixa renda, ao passo em que ocorre uma diminuição dos turistas que viajam pelo mesmo motivo à medida em que demonstram uma renda maior.

Segundo dados obtidos do site Marketing.com.br, o mercado religioso no Brasil, possui um público consumidor de 26 milhões de pessoas, de todas as classes sociais, que movimento cerca de $\mathrm{R} \$ 3$ bilhões por ano. ${ }^{21}$

Além dos motivos que levam o turista deste segmento a lugares santos para comemorações de datas, a lugares que manifestaram aparições de santos ou milagres constatados ou não pelo Vaticano (sede oficial do Papa), o turismo religioso pode levar o turista a praticar outras modalidades turísticas, de acordo com a potencialidade de cada região visitada, com diversos outros atrativos, como pontos históricos, museus, cidades históricas, manifestações culturais, eventos e etc.

O turismo religioso expressa o grande sentimento de fé e caridade dos brasileiros por meio das romarias e peregrinações a diversos lugares religiosos, podendo ocorrer de forma organizada ou individual, programadas ou definidas pelos próprios turistas de acordo com a motivação religiosa e os dogmas de cada um.

No turismo religioso, no Brasil, destacam-se como principais receptores os estados, do Ceará (33,7\%); São Paulo (19,3\%); Bahia (14,3\%) e Rio de Janeiro $(12,4 \%)$, acumulando quase $80 \%$ do total dessas viagens. ${ }^{22}$

\footnotetext{
${ }^{20}$ http://www.sindetur.com.br/turismo_em_numeros/estatistica_13.pdf. Acesso em 19, mar, 2004.

${ }^{21} \mathrm{http} / / /$ www.marketing.com.br, acesso em 03 de março de 2004.

22 http://www.sindetur.com.br/turismo_em_numeros/estatistica_13.pdf. Acesso em 19, mar, 2004.
} 
As potencialidades de determinados Estados e Regiões do Brasil, conforme demonstrado, revelam a importância de se criar projetos que preencham de forma substancial, as necessidades específicas do segmento religioso, como forma de acompanhamento de seu crescimento junto aos turistas.

Os números indicam que os valores sociais de uma região para outra podem ser tratados como indícios de um mercado em expansão e pouco explorado, se comparados com destinos ainda pouco expressivos e que não aparecem nas pesquisas e nos dados estatísticos de órgãos de referência.

\section{1 - O SENSO DE CIDADE E O TURISMO RELIGIOSO}

A noção de cidade, proposta por diversas análises, se afasta dos referenciais sociais, por uma simples leitura de dados quantitativos, onde o que se considera são apenas números e não a relação entre seus habitantes. A cidade é mais que um aglomerado de edificações e sim um conjunto intrincado de manifestações sociais e culturais. Os lugares, devem, se confundir com os seus habitantes.

Através dos estudos históricos, pode-se compreender o movimento da sociedade na construção dos espaços na cidade. Esses movimentos construtores de espaço são, muitas vezes, de cunho cultural. A cidade pode ser entendida como "um espaço que traduz uma certa peculiaridade de lugar construído pelas experiências e pensamentos de homens, indicando que o universal está nas ações dos homens." ${ }^{23}$ Para Deusdedith Junior ${ }^{24}$, outros sinais surgem da cidade quando se busca nela as coisas triviais, percebendo-a deste modo consiste em acompanhar seu movimento.

\footnotetext{
${ }^{23}$ Rodrigues, 1996, p. 58
} 
A cidade é palco de diversas manifestações culturais, dentre elas, a místico-religiosa, onde seus personagens desempenham papel fundamental na massificação do turismo. O turismo também é considerado uma dessas manifestações, e de acordo com Beni: "os recursos turísticos culturais são, pois, os produtos das manifestações culturais". ${ }^{25}$ Como Beni ressalta, pode-se aliar as práticas religiosas às práticas turísticas, e usar a cidade como palco.

A cidade de Aparecida, em São Paulo, é um exemplo claro da união da prática religiosa católica com o turismo convencional ou doméstico. Mas observase que não se trata de um exemplo isolado, existindo outras cidades, como Congonhas em Minas Gerais, outras práticas religiosas e outras práticas turísticas.

Diante desses fatores, pode-se aglutiná-los e criar uma nova modalidade, chamada Ponto de Atração de Fé. Diferentemente dos atrativos naturais e dos construídos pelo homem, pois trata-se de uma manifestação cultural transcendente, tanto ao homem, como à cidade.

\section{6 - CONCLUSÃO}

Embora haja um perfil sucinto do turista do segmento religioso no Brasil, revelado através de pesquisas, há a necessidade de um maior compromisso dos órgãos públicos e privados em desenvolver projetos de qualidade, que priorizem a qualidade de vida dos turistas brasileiros, que visitam outros Estados e Regiões, assim como, os turistas de outros países.

A fim de atribuir qualidade à prestação de serviços em conjunto com produtos formatados de acordo com as necessidades e desejos dos clientes, 0

\footnotetext{
${ }^{24}$ Deusdedith Junior, 2003, p. 139

${ }^{25}$ Beni, 1998, p. 84
} 
marketing com suas ferramentas e técnicas adaptáveis a cada tipo de situação, demonstra ser o meio mais adequado para se atingir os objetivos esperados em cada trabalho dentro do turismo.

Sabe-se que a expectativa do cliente, quanto aos atributos que considera mais relevantes, seja atendida, como: os atributos básicos, os atributos esperados e aqueles inesperados, dependendo do investimento e do tipo de produto que esteja comprando.

Desta forma, devem ser contemplados todos os projetos que se façam presentes no setor do turismo e no segmento que cada vez mais ganha a simpatia de pessoas em todo o Brasil, como o religioso.

O ponto de fé traçado à partir da leitura da cidade, vista como forma de organização social, permite conceituar os locais de práticas místico-religiosas, quanto ao valor coletivo das pessoas com o espaço físico.

Deste modo, chega-se às formas tangíveis e intangíveis que caracterizam o ponto de fé em relação aos turistas.

O turismo religioso pode motivar as pessoas a praticarem outras modalidades de turismo, dependendo da localidade onde esteja inserido. O ponto de fé, como proposta, pode também ser entendido pelo turista como um local de retorno para a prática do turismo, pela boa receptividade, pelos atrativos disponíveis e pelo rápido acesso, conforme as boas condições de infra-estrutura.

Não se pode pensar em segmentar esse tipo de turismo de massa em partes menores, fazendo uso das técnicas de marketing, de modo a controlar o fluxo de turistas que marcham em multidões como romarias e peregrinações, pois corre-se o risco de descaracterizar o evento religioso. As datas já fazem parte da vida dos fiéis, que religiosamente retornam nos próximos anos. Neste caso, deve- 
se usar o marketing para divulgação do evento, para os turistas que ainda não conhecem o local, na melhoria do trade turístico, fomentando novos projetos locais para maior comodidade dos turistas e que vise, sobretudo, a qualidade de vida da comunidade local.

\section{7 - BIBLIOGRAFIA}

ALVES, Rubem Azevedo. O que é religião. São Paulo: Brasiliense, 1984.

ANSARAH, Marília Gomes dos Reis. Turismo: Segmentação de Mercado. São Paulo: Futura, 1999.

BENI, Mário Carlos. Análise Estrutural do Turismo. São Paulo: SENAC, 1998.

BOCOCK, R \& THOMPSON, K. (org.) Religion and Ideology. Manchester: Manchester University Press/ The Open University, 1985

COBRA, Marcos. Marketing de Turismo. São Paulo: Cobra Editora \& Marketing, 2001.

DURKHEIM, Émile. As formas elementares da vida religiosa: o sistema totêmico na Austrália. São Paulo: Martins Fontes, 1996.

IKEDA, Ana Akemi. O Marketing em Empresas de Pequeno Porte e o Setor de Serviços: Um estudo em Agências de Viagens. Brasília: SEBRAE, 1995.

KOTLER, Phillip. Marketing. São Paulo: Ed. Atlas, 1996. 
ROCHA JUNIOR, Deusdedith Alves. "A Cidade é um texto: apontamento para ler a cidade. In: Revista Universitas/Face, Brasília, v. 1, n. 1, 2003.

RODRIGUES, Antônio Edmilson Martins. Cultura urbana e modernidade: um exercício interpretativo. In: - Cultura. Substantivo plural. São Paulo: Editora 34, 1996.

RABAHY, Wilson Abrahão. Caracterização do turismo: uma análise das motivações "Feiras e Congressos" e "Religiosa". Caderno de Estatísticas, São Paulo (SP). Disponível em $<$ http://www.sindetur.com.br/turismo_em_numeros/estatistica_13.pdf>. Acesso em 19 de março de 2004.

SIQUEIRA, Deis. As novas religiosidades no Ocidente: Brasília, cidade mística. Brasília: Unb, 2003.

. "Religiosidade e Turismo em Brasília". Apostila do Centro de Excelência em Turismo da Universidade de Brasília, abril, 2003

SOARES, Luiz Eduardo. O rigor da indisciplina. Rio de Janeiro: RelumeDumará, 1994.

TURNER, Victor Witter. Dramas, fields, and metaphors: Simbolic Action in Human Society. New York: Cornel University Press, 1975.

VAZ, Gil Nuno. Marketing Turístico: Receptivo e Emissivo. São Paulo: Pioneira, 2001. 